A SEAT AT

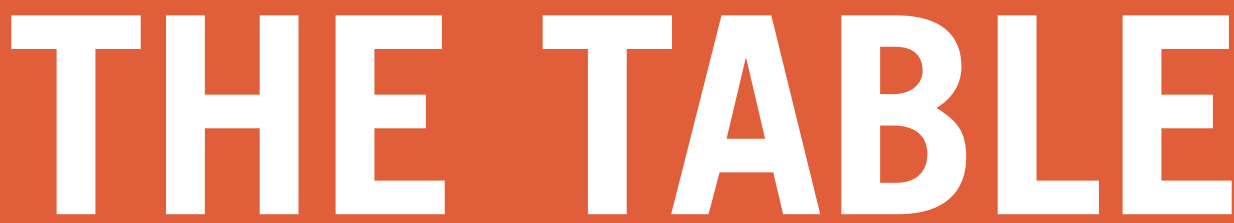

Including the Poor in Decisions for Development and Environment

Joseph Foti and Lalanath de Silva

Based on the Findings of the Access Initiative
WORLD

RESOURCES

I NSTITUTE

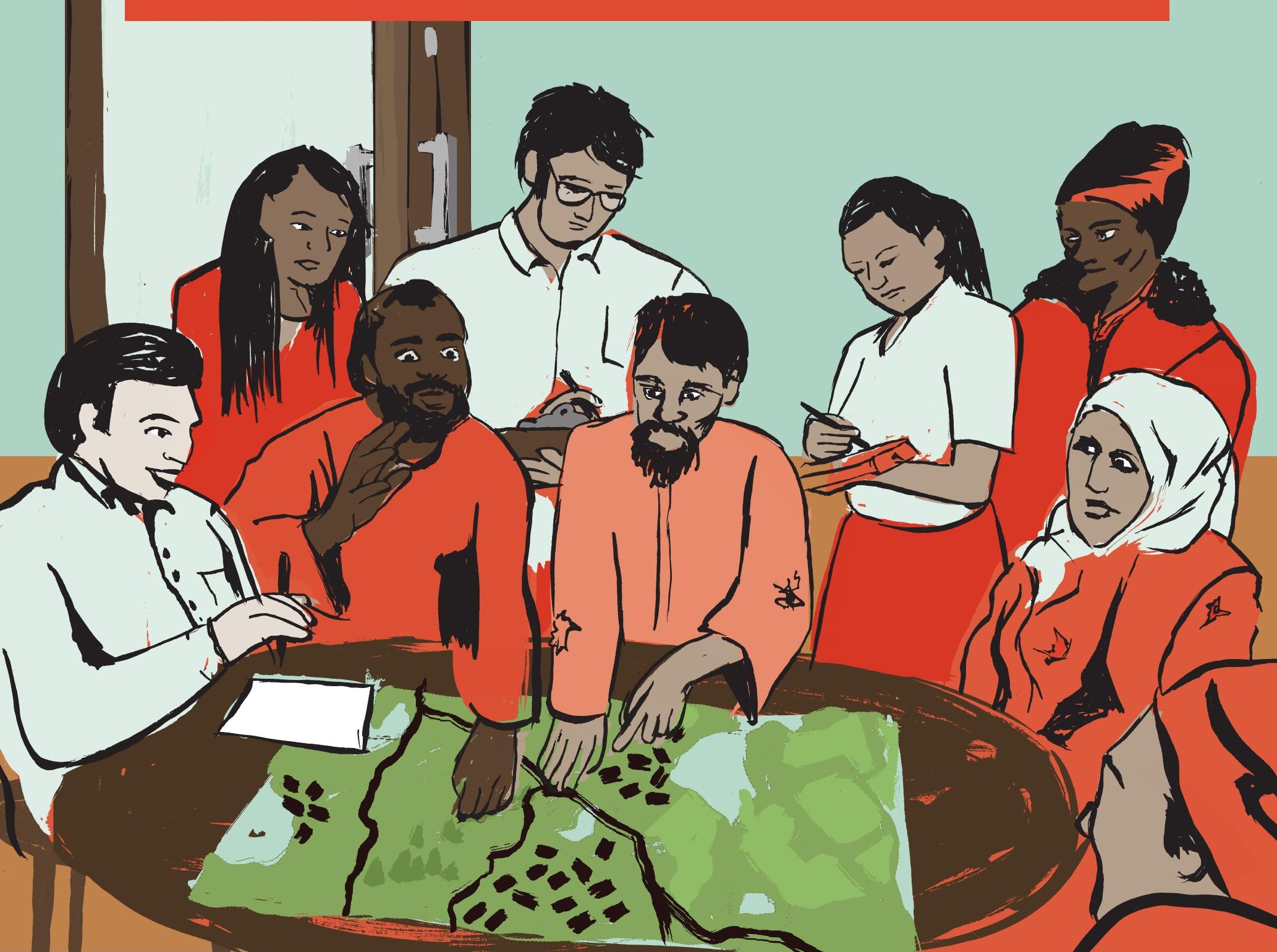




\title{
A Seat at the Table \\ Including the Poor in Decisions for Development and Environment
}

\author{
Joseph Foti
}

\section{Lalanath de Silva}

Based on research conducted by:

Foundation for Environment and Development, Cameroon

Instituto de Derecho Ambiental, Paraguay

Ateneo School of Government, Philippines

Public Interest Law Foundation, Sri Lanka

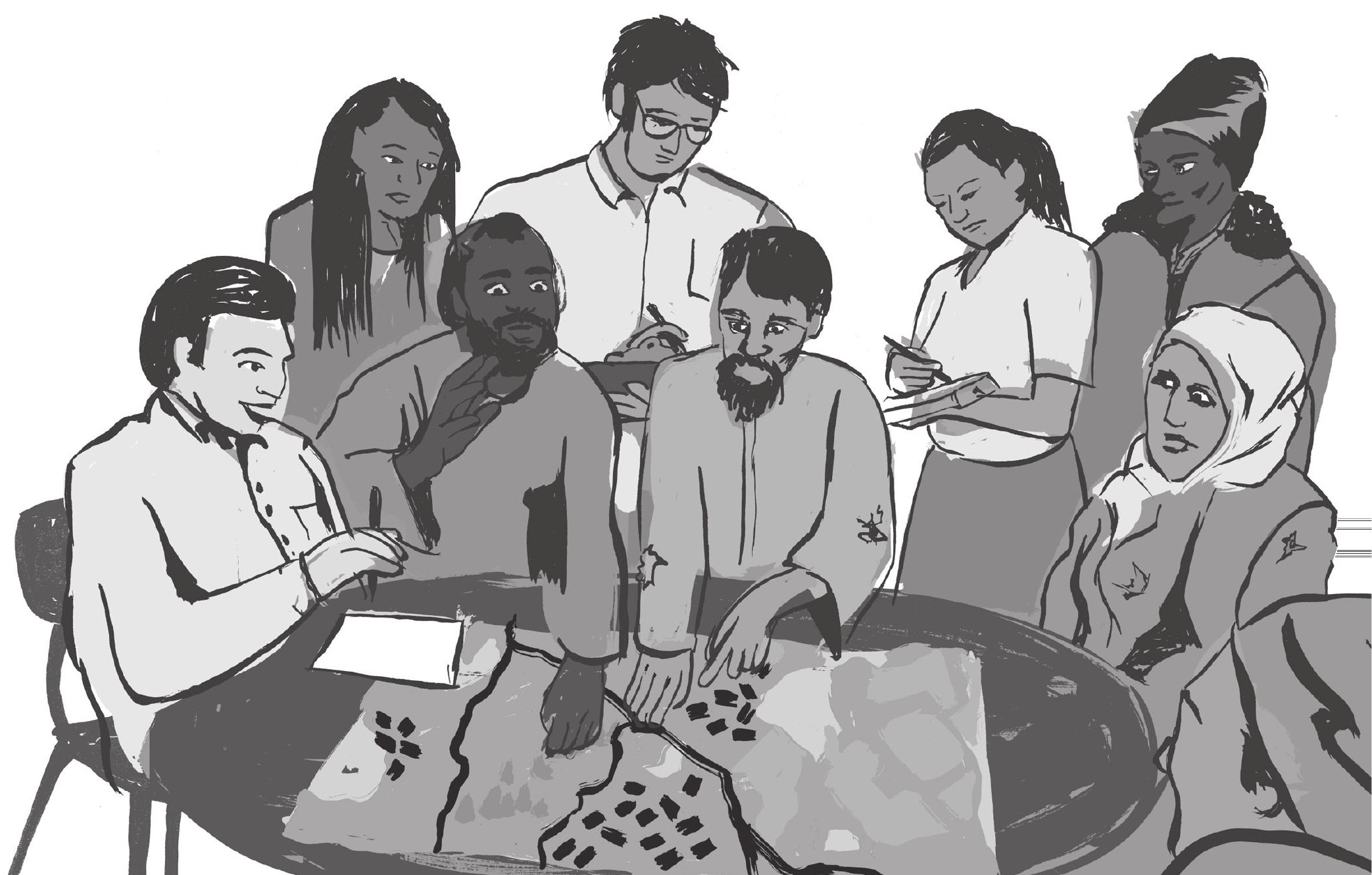




\section{April Osmanof}

Cover design

\section{Maggie Powell Designs}

Report design and layout

Each World Resources Institute report represents a timely and scholarly treatment of a subject of public concern. WRI takes responsibility for choosing the study topics and guaranteeing its authors and researchers freedom of inquiry. It also solicits and responds to the guidance of advisory panels and expert reviewers. Unless otherwise stated, however, all the interpretations and findings set forth in WRI publications are those of the authors.

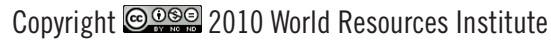
This work is licensed under the Creative Commons AttributionNoncommercial-No Derivative Works 3.0 United States License.

ISBN: 978-1-56973-740-8

Printed on recycled paper with recycled content of $55 \%$,

$30 \%$ of which is post consumer.

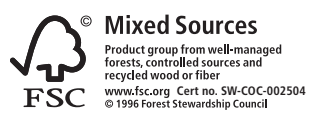




\section{Contents}

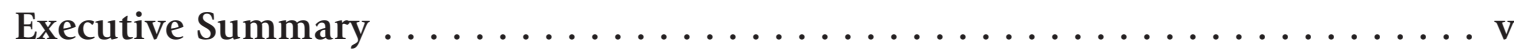

1. Access Rights and Poverty Today $\ldots \ldots \ldots \ldots \ldots \ldots \ldots \ldots \ldots \ldots$

1.1 Current access standards . . . . . . . . . . . .

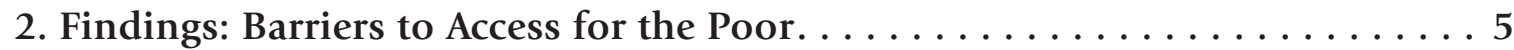

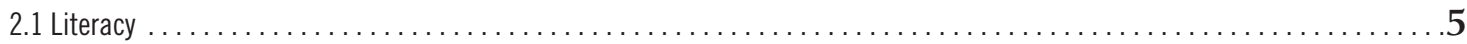

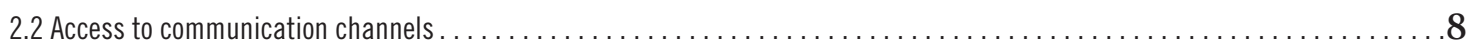

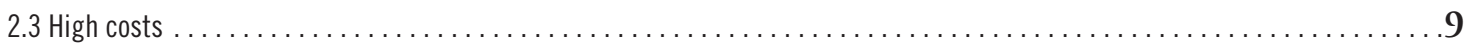

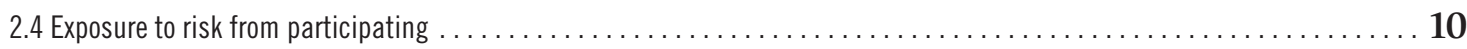

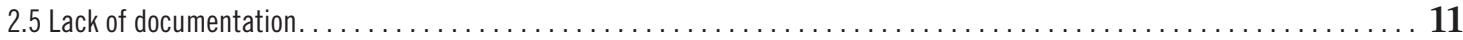

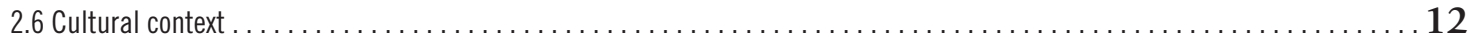

3. Recommendations: Leveling the Access Playing Field . . . . . . . . 15

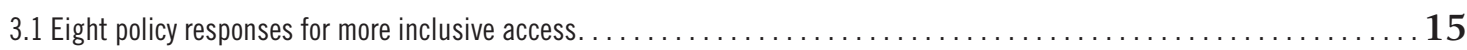

Policy response 1: Identify the poor and establish thresholds for enhanced access

Policy response 2: Use the right form to communicate

Policy response 3: Use the right channels to communicate

Policy response 4: Reduce costs

Policy response 5: Defend the organizations and individuals that promote access

Policy response 6: Clarifiy resource-related rights and remove legal barriers of standing and evidence

Policy response 7: Build capacity and raise awareness

Policy response 8: Make the voice of the poor influential

3.2 Four steps to institutionalize more inclusive access ...

Step 1: Create access rights

Step 2: Ensure equal application of access rights

Step 3: Ensure equal ability to use access rights

Step 4: Create additional rights that ensure the ability of the poor to use access rights

Criticisms and considerations of more inclusive access

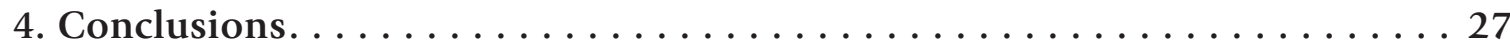

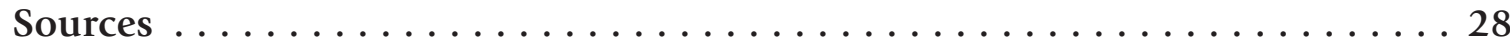




\section{Research Teams}

\section{CAMEROON}

Nchunu Justice Sama, lead researcher

Peter Chili

Paul Ndue

Prudence Galega

Bih Tawah Electha

\section{PARAGUAY}

Patricia Abed, lead researcher

Marina del Mar Zavale

\section{PHILIPPINES}

Loraine Gatlabayan, lead researcher

Ramon Fernan III

Jose Florante Pamfilo

Miguel Magalang

\section{SRI LANKA}

Sonali de Silva, lead researcher

Ruana Rajapakse

Mihiri Gunewardene

Piyumali Perera

Himalie Siyambalapitiya

Indika Priyanthalal

Indira Fernando

Michael O'Leary

\section{Acknowledgments}

The authors would like to thank Janet Ranganathan, Polly Ghazi, and Jacob Werksman for their guidance throughout the process of writing A Seat at the Table. Kulsum Ahmed, Patricia Abed, Justice Nchunu, Sonali de Silva, and Ruana Rajapakse provided critical research and insightful reviews. We also appreciate the help of Frances Irwin, Britt Staley, Norbert Henninger, Kirk Herbertson, and Anne-Gaelle Javelle, whose insights contributed significantly to the report. Thanks are due to

Lesly Baesens, Monika Kerdeman, and Hyacinth Billings who helped to usher the report through to its completion. Finally, funding for this report and the work of the Access Initiative is provided by the World Bank, the Swedish International Development Cooperation Agency, the Danish International Development Agency, the Dutch Ministry of Foreign Affairs, Irish Aid, the United Kingdom Foreign and Commonwealth Office, and the Libra Foundation.

It is a wise man who said that there is no greater inequality than the equal treatment of unequals. 


\section{Executive Summary}

Decisions that have significant environmental and social consequences are often made without the involvement of those whose interests are directly at stake. For poor people whose lives and livelihoods often depend on natural resources, and who are therefore most vulnerable to environmental risks, the consequences of exclusion can be especially severe. Weak access to decision-making may expose poor communities to high levels of pollution, remove them from productive land, and deprive them of the everyday benefits provided by natural resources.

The three pillars of sound decision-making for the environment that are key to responding to the challenge of providing "access" are: access to information, public participation, and access to justice. Many countries, regardless of their level of economic development, have promoted these pillars as policy aspirations or as enforceable legal rights. Yet even where progress has been significant, more work remains if such laws are to be implemented in a way that is meaningful to all citizens, especially the poor.

To better understand the obstacles to access facing the poor, and the efforts by governments to reach this population, the World Resources Institute (WRI) and its civil society organization (CSO) partners in The Access Initiative $^{1}$ (TAI) closely examined access rights and practices in four countries-Cameroon, Paraguay, Philippines, and Sri Lanka. ${ }^{2}$

The case studies highlighted in this report cover a range of environmental concerns including water quality, land use, data availability, and the use or absence of environmental impact assessments (EIAs). The findings and literature review show that the poor in these countries face a daunting array of barriers to access, including low literacy, high costs (including the costs of corruption), exposure to risk from participation, and lack of documentation of legal identity or rights to a resource that is necessary to influence decisions. Additionally, cultural norms that limit who may speak in public disproportionately exclude the poor.

The case studies also provide examples where civil society organizations, community groups, and-most importantly-governments have taken steps to overcome these barriers. Based on the findings and literature review, we have identified six poverty-related barriers to access to decision-making and proposed eight categories of policy responses to overcome these barriers (see Table 1). Importantly, a general lack of access to information for all citizens had a commensurately larger impact on access to information for the poor.

\section{RECOMMENDATIONS}

The above list of barriers and policy responses are not intended to be exhaustive, but rather a starting point for an action agenda. Below we make recommendations on how governments, civil society, and donors can implement each response, based on positive examples drawn from our case studies and elsewhere.

Policy response 1: Identify the affected poor and establish thresholds for enhanced access In determining strategies to strengthen access, identify the poor with a stake in the outcomes of decisions. Dedicate resources to reach out to these individuals and communities. Establish clear guidance for officials around thresholds to provide enhanced access. 
TABLE 1 BARRIERS TO ACCESS FOR THE POOR AND POLICY RESPONSES

\begin{tabular}{|c|c|}
\hline BARRIER & POLICY RESPONSE \\
\hline LACK OF LEGAL THRESHOLDS FOR ENHANCED ENGAGEMENT & 1. Identify the poor and establish thresholds for enhanced access \\
\hline $\begin{array}{l}\text { LITERACY } \\
\text { basic reading skills } \\
\text { ability to understand technical content } \\
\text { language }\end{array}$ & $\begin{array}{l}\text { 2. Use the appropriate form: ensure that information around decisions and } \\
\text { opportunities to influence decisions for the environment matches the technical } \\
\text { understanding, literacy levels, and native languages of the poor }\end{array}$ \\
\hline $\begin{array}{l}\text { ACCESS TO COMMUNICATION CHANNELS } \\
\text { poor physical access to information technology such as Internet, papers, } \\
\text { television, radio, text messaging }\end{array}$ & $\begin{array}{l}\text { 3. Use the appropriate channels: ensure that information around decisions and } \\
\text { opportunities to influence decisions for the environment is communicated through } \\
\text { channels used by the poor }\end{array}$ \\
\hline $\begin{array}{l}\text { COST } \\
\text { official fees } \\
\text { travel } \\
\text { foregone work } \\
\text { time constraints } \\
\text { cost of childcare } \\
\text { corruption }\end{array}$ & $\begin{array}{l}\text { 4. Reduce costs: remove barriers, reduce official fees, and provide subsidies for } \\
\text { participation }\end{array}$ \\
\hline $\begin{array}{l}\text { EXPOSURE TO RISK FROM PARTICIPATING } \\
\text { personal risk (physical or psychological intimidation) } \\
\text { property risk (threat of expropriation, burglary, etc.) }\end{array}$ & 5. Defend the individuals and organizations that promote access \\
\hline $\begin{array}{l}\text { OFFICIAL DOCUMENTATION } \\
\text { lack of legal identity } \\
\text { burden of proof }\end{array}$ & 6. Remove legal barriers of standing and evidence \\
\hline $\begin{array}{l}\text { CULTURAL CONTEXT } \\
\text { expectations about who has a "voice" } \\
\text { meaningfulness of participation }\end{array}$ & $\begin{array}{l}\text { 7. Build capacity and raise awareness } \\
\text { 8. Make the voice of the poor influential }\end{array}$ \\
\hline
\end{tabular}

Policy response 2: Communicate information in the most effective form

To the greatest extent possible, make sure that environmental information made available is useful and useable in informing decisions.

Policy response 3: Communicate through the most effective channels

Communicate information through culturally appropriate channels_radio, bulletin boards, or religious institutions, for example. Where information and communication technology is rare or unavailable, use lowtech solutions such as posting signs or communicating through local governments.

\section{Policy response 4: Reduce costs}

Design logistics and provide services and subsidies to lower access costs. Offer no-cost or sliding scale fees for the poor to access information, procedures, and courts. Hold public procedures as close to affected communities as possible.
Policy response 5: Defend the individuals and organizations that promote access Support and protect individuals and organizations that work to inform the poor from recrimination- by building capacity and raising awareness. This includes non-governmental organizations, local governments, and media outlets.

Policy response 6: Clarify identity and resourcerelated rights, and remove legal barriers to standing and evidence

Establish clear legal rights to resource use by means such as property registration. Ensure that all individuals have low-cost, efficient means of obtaining legal identification. If such reforms cannot be achieved in the short run, rules of standing and evidence should be waived or loosened for poor individuals.

Policy response 7: Build capacity and raise awareness Promote the "voice" of poor individuals by improving their technical understanding of process and by helping them overcome the lack of confidence and cultural barriers that can silence the poor in public processes. 
Policy response 8: Make the voice of the poor influential

Meaningful participation requires both including stakeholders early enough in the process to influence decision-making and holding officials accountable to address the public's concerns. Facilitators must "go out of the way" to engage those members of the community who might not otherwise be consulted. The results of participation should be well documented and disseminated. Officials responsible for decisions and for managing participation should be answerable for such processes.

These eight policy responses constitute an action agenda for civil society, governments, and donors to ensure that the poor are able to exercise general access rights in a manner equal with other citizens. The pace at which countries will implement this agenda will vary.

Based on the evidence gathered in this report, we also identified four overarching steps that governments can take to institutionalize equal enjoyment of access rights for the poor:

1. Create access rights - requires development of the basic legal framework for access to information, public participation, and access to justice.

2. Ensure equal application of access rights - requires an absence of official discrimination and the ability of all individuals to equally participate. An especially important aspect of the equal application of rights will be a review and removal of the legal and cultural barriers that affect the poor, such as restriction on the right to inherit land by women or awareness raising around the right of low-caste individuals to participate in meetings.

3. Ensure equal ability to use access - requires programs that develop citizens' abilities to use access by reducing costs and improving means of communication.

4. Create additional rights that ensure the ability to use access rights - creates a legal obligation on the part of governments to develop specific tools to address the capabilities of the poor. Grants citizens legal mechanisms to ensure that such rights are enforced.

In the context of today's pressing environment and development challenges-including climate change, ecosystem degradation, and urbanization-the success of decisions affecting the environment is of great importance. Successful decision-making depends in part on perceptions of legitimacy, which in turn depend on the fairness and inclusiveness of the process as well as the just distribution of costs and benefits. Policies that ensure public access to information, public participation, and access to justice are crucial, and this report seeks to promote avenues for policymakers to ensure that they are applied equitably, including to the poorest in society.

\section{Research approach}

To investigate the ability of the poor to influence decisions, WRI worked with CSOs in four countries to evaluate how well governments provided access to individuals and communities living in poverty. The four countries (with corresponding partner organizations in parentheses) were Cameroon (Foundation for Development and Environment - FEDEV), Paraguay (Institute for Environmental Law - IDEA), Philippines (Ateneo School of Government), and Sri Lanka (Public Interest Law Foundation - PILF). Countries were chosen based on diversity of geography and legal systems, a history of successful work with a TAI partner, and having a significant portion of the population living in poverty.

Each partner undertook its study in several stages:

- Identification of case studies in impoverished communities. Partners drew on official definitions of poverty in each country (for example, per capita income, per capita receiving government welfare) and described their specific characteristics (for example, percentage defined as poor, the presence of indigenous groups, or of linguistic and cultural minorities).

- Analysis of the extent to which law requires officials to make additional efforts to ensure that the poor can exercise their rights of access. Legal research included analysis of constitutional and statutory rights to a clean environment; access to information, public participation, and access to justice; as well as rights of assembly, association, and expression.

- Evaluation of how well existing legal rights to access were implemented. Partners applied uniform indicators to case studies highlighting each of the access pillars to gauge efforts made to reach out to and involve poor communities in official processes. ${ }^{3}$

- Examination of recent official decision-making processes. Partners were at liberty to choose which 
specific processes they would use to highlight the availability of information, public participation, or justice. Case studies were selected based on "typical" practice that demonstrated common official approaches to providing access to an affected poor community, as defined by the partners.

Table 2 shows the processes examined by each organization. Cases selected for access to information emphasized emergencies. Public participation case selection focused on environmental impact assessments, and access to justice cases dealt almost exclusively with environmental harms.
Because of the small sample and the absence of a time series, this study cannot be used to identify trends within a country or provide comparison across countries. Rather, the intent was to create an inventory of barriers to access for the poor, identify positive steps some governments have taken to address these challenges, and note any common experiences across countries.

\section{TABLE 2 CASE STUDIES BY TOPIC AND COUNTRY}

\begin{tabular}{|c|c|c|c|c|c|c|}
\hline & & CAMEROON & PARAGUAY & PHILIPPINES & SRI LANKA & TOTAL \\
\hline \multirow{4}{*}{ 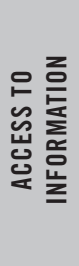 } & Water quality & 1 & & 1 & & 2 \\
\hline & Facility-level data & 1 & & & & 1 \\
\hline & Environmental emergency & & 2 & 1 & 1 & 4 \\
\hline & Environmental impact assessment & & & & 1 & 1 \\
\hline \multirow{3}{*}{ 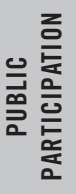 } & Environmental impact assessment or project & & 1 & & 3 & 4 \\
\hline & Policy formation & & & 1 & & 1 \\
\hline & Participatory management & & & 1 & & 1 \\
\hline \multirow{2}{*}{$\begin{array}{l}\text { 은 } \\
\text { 岕 } \\
\text { 岕点 } \\
\text { 宅 }\end{array}$} & Environmental harm & 1 & 3 & 2 & 1 & 7 \\
\hline & Land use & 1 & & & & 1 \\
\hline
\end{tabular}




\section{Access Rights and Poverty Today}

The villagers knew nothing of the new expressway. They awoke one morning to find surveyors, engineers, and other officials walking their lands-taking measurements, making maps, and questioning people. They discovered that a sixlane expressway was planned to run through their villages and that they would be forcibly relocated from their ancestral homes. To make way for the expressway from the Sri Lankan capital, Colombo, to the southern city of Matara, the government was planning to forcibly relocate hundreds of people from the three villages of Kahatuduwa, Gelenigama, and Akmeemana.

Most of the villagers were poor. Some were rice farmers working small holdings; others were day laborers. Some worked for local small businesses or local government. Many had families with schoolchildren. Few had the funds, time, or energy to seek more information or get relief from the crisis. But if they didn't, they would all lose their homes, their way of life, and their heritage.

Among the villagers were a few affluent and educated people who knew how to reach government officials. Slowly, the villagers began to organize themselves. A wealthy few led the effort to form a "Gama Surakeeme Sanvidanaya" (Village Protection Society). They mobilized the villagers and collected facts to make a case for redress. Those who could, contributed funds. The poorer villagers pooled what they could scrape together.

The villagers contacted the Public Interest Law Foundation (PILF) and other civil society groups in the capital Colombo. The case quickly became larger than the village. Soon, several public interest lawyers were pouring over legal precedents, documents, and case material. They were figuring out how to approach the courts in a case that involved the longest expressway on the island, an expressway that would stretch 126 kilometers.
PILF and other civil society groups sent out teams of volunteers and experts to investigate the villagers' complaints. They documented the injustices that had occurred. After the expressway route had been approved, following an environmental impact assessment and public hearing, the Road Development Authority had secretly changed the route to go through the three villages. In violation of Sri Lankan law, the government had failed to provide opportunities for the villagers to participate in the final decision-making.

The case eventually reached a resolution, with the villagers of Kahatuduwa, Gelenigama, and Akmeemana justly compensated for their eviction. But this case was the exception rather than the rule; the civil society groups were fortunate to have their own funds that added to the funds of the Village Protection Society. While many such cases arise in poor neighborhoods, few communities have such access to relief and remedy.

Though the villagers in Sri Lanka ended up receiving just compensation, the story demonstrates some of the difficulties surrounding decision-making and the involvement of poor communities. The key elementsenvironmental harms; loss of livelihood or property; decisions made without the involvement of those affected; and the inability of individuals, especially poor individuals, to exercise their rights-are common across borders and contexts. Other less visible scenarios where communities do not have similar resources may result in adverse environmental and social outcomes. For the poor, whose lives and livelihoods often depend on natural resources and who are most vulnerable to environmental risk, consequences can be especially severe. Lack of ability to take part in decisions, deprivation of political freedoms, and little ability to influence public policies and political priorities are specific 
problems. They can result in unfair or even harmful decisions which can lead to a loss of livelihood or wellbeing (World Resources Institute 2004).

Access to information, public participation, and access to justice-referred to here as "access" — play a significant role in ensuring that individuals are able to enjoy a clean and safe environment. Many countries, regardless of economic position, have promoted these access "pillars" through aspirations to enforceable legal rights (Foti et al. 2008) (see Box 1, "Defining Access" for further definitions of these pillars). The practice of openness has become increasingly ingrained in political cultures across the globe. National laws have spread and binding treaties such as the Aarhus Convention have come into effect (Foti et al. 2008; UNECE Convention on Access to Information, Public Participation in Decision-Making and Access to Justice in Environmental Matters 1998). Freedom of information laws have increased considerably over the past ten years (Banisar 2008; Neuman 2009). Environmental impact assessment procedures in a large number of countries now require public participation in some stages of project and plan development (Wood 1997).

Yet even where this progress has been significant, work remains to be done if these laws and policies are to be meaningful to all citizens. The poor, even when legally entitled to information, participation, and justice, may not have the ability to exercise these rights due to constraints of cost, time, and capability (CLEP 2008). At times, lack of voice may be due to broader social conditions, such as beliefs about who is able to raise their voice, a closed political system, or weak accountability of officials due to corruption in key institutions such as courts. Thus, the current widely accepted standards of access to information, public participation, and access to justice are insufficient to effectively engage all citizens.

Enabling individuals and communities to use their voice to influence decisions can directly address elements of poverty. While voice in environmental decisions can make a significant difference in the allocation of resources and people's ability to use those resources, voice also plays a role in ensuring a sense of involvement and in helping individuals gain a sense of control over their lives (Foreman 1998). These too are important aspects of poverty alleviation (Sen 2001). Box 2 outlines elements of poverty using a broad approach, including the ability to influence political decisions.

\section{BOX 1 DEFINING ACCESS}

Access: Access to information, public participation, and access to justice; these principles strengthen the right to a healthy or safe environment and are in turn strengthened by an established, enforceable right to a healthy or safe environment.

Right to a clean environment: The right to a clean and healthy environment is a legally enforceable right in more than 80 countries. It may be explicit or it may derive from other rights such as land and water rights or the right to life. The specific, enforceable content of the right to a clean environment varies across jurisdictions (Kravchenko and Bonine 2008).

Access to information: Refers to (1) the availability of information relating to the environment and (2) the mechanisms by which public authorities provide environmental information (Excell and Thompson forthcoming).

Public participation: Refers to the availability of opportunities for individuals, groups, and organizations to provide input to decision-making that will have — or is likely to have_-an impact on the environment (Excell and Thompson forthcoming).

Access to justice: Refers to effective judicial and administrative procedures and remedies available to individuals, groups, and organizations for actions that affect the environment and contravene laws or rights. The legal standing to sue and the ability to litigate are components of access to justice (adapted from Kiss and Shelton 2006).

In addition to the need for policy to improve access, there is a significant gap in the academic literature with regard to access for poor communities and individuals in decisions that impact the environment. While the literature on public participation and poverty is extensive, it approaches the subject largely from the perspective of community-based natural resource management, rather than from the perspective of broad frameworks such as environmental impact assessments and their ability to provide fair procedures for people living in poverty (Ribot 2002; Cooke and Kothari 2002). This gap in the literature is one of the key motivations behind our research.

A Seat at the Table examines the impediments poor communities face in exercising access rights based on case studies in four developing countries, Cameroon, Paraguay, Philippines, and Sri Lanka. The case studies were carried out by members of the Access Initiative, a network of CSOs engaging in research and reform to improve access around the world. 


\section{BOX 2 DEFINING POVERTY}

Poverty is multifaceted. A definition based solely on material wealth cannot capture the cultural and psychological aspects of poverty in many countries. As used in this paper, the term "poverty" refers not only to deprivation of material assets but also to the inability to fully participate in economic, social, and political life, or "social exclusion" (Zheng and Walsham 2008).

Poverty may include a variety of deprivations: economic deprivations (the ability to earn income; to consume; to have assets and access to food, security, material wellbeing, and social status); human deprivations (based on health, education, nutrition, clean water, and shelter); political deprivations (human rights, a voice and some influence over public policies and political priorities, deprivation of basic political freedoms or human rights); socio-cultural deprivation (ability to participate as a valued member of a community, social status, dignity, and other cultural conditions for belonging to a society that is highly valued by the poor themselves); and a lack of resilience (ability to withstand economic shocks) (Robeyns 2005).

As a result, poverty can coexist with material wealth and is directly related to the ability to participate in political decisions as a member of a community (Zheng and Walsham 2008). One consequence of this situation is that many of the findings of this report can apply equally to rich as well as poor countries.

On the basis of these studies and a review of recent research on this topic, we identify eight categories of barriers and corresponding policy responses that might help poor individuals exercise their access rights. We suggest that these policy responses form the basis of future global and national standards for access to information, public participation, and access to justice. We also propose four steps that legislatures and executives can take to ensure more inclusive access to decisionmaking for the environment. It is our hope that this report will inspire "access proponents" interested in advancing more effective regimes for official decisionmaking-including individuals in civil society organizations, innovators in government, and donor agenciesto adopt and work for a new and more inclusive standard of access.

This report does not address the historical roots of many movements for access for the poor. In countries where progress has been made, such as South Africa, South Korea, and the United States, much of that progress has its roots in larger, protracted political struggles
(McDonald 2002; Massachusetts Executive Office of Energy and Environmental Affairs 2010; Seo 2002). At times, countries have taken steps to correct historical injustices by putting affirmative action laws or quotas in place to give preference to members of marginalized groups. While such policies may be valid, this paper focuses on "leveling the access playing field" to ensure that the rights guaranteed to all are enjoyed by all.

\subsection{Current access standards}

In Voice and Choice: Opening the Door to Environmental Democracy, WRI researchers demonstrated that policies based on access pillars have been adopted in many countries as part of a growing movement toward "environmental democracy." Freedom of information laws have been adopted in most countries worldwide (Banisar 2008), and court systems are increasingly open to public interest cases (Excell and Thompson forthcoming).

Where this has occurred, the prevailing standards of access arise primarily from specific experiences such as journalists fighting for information, communities wanting to know about the toxic materials to which they are exposed, or citizens seeking access to courts. Countries that have moved toward environmental democracy have not specifically focused on making information useful to the poor in most cases. This is a limitation that needs to be addressed.

Consequently, the reforms that comprise this progress are largely focused on the availability of procedures, rather than the usability of these procedures. For example, Voice and Choice showed that for access to information to be usable, we need systems that push information out to the public in meaningful ways, and that opportunities for the public to participate in decisionmaking include all relevant stakeholders. This is especially true for the poor, who may have limited ability to access and interpret official information.

Current global and regional standards for promoting access do not specifically address the special concerns of the poor. At the international level, Principle 10 of the Rio Declaration from the World Summit on Sustainable Development recognizes that:

Environmental issues are best handled with participation of all concerned citizens, at the relevant level. At the national level, each individual shall have appropriate access to information concerning 
the environment that is held by public authorities, including information on hazardous materials and activities in their communities, and the opportunity to participate in decision-making processes. States shall facilitate and encourage public awareness and participation by making information widely available. Effective access to judicial and administrative proceedings, including redress and remedy, shall be provided. (UNCED 1992)

As it has been carried out, the Declaration emphasizes availability of information and opportunities for participation, without specifying other characteristics of access to information such as publicity or usability of information. These issues may be of equal importance for involving poor communities. Other portions of the Rio Declaration (Principle 22 in particular) seem to suggest that additional steps should and can be taken to improve access, especially public participation:

Indigenous people and their communities and other local communities have a vital role in environmental management and development because of their knowledge and traditional practices. States should recognize and duly support their identity, culture and interests and enable their effective participation in the achievement of sustainable development. (UNCED 1992)

The UNECE Convention on Access to Information, Public Participation in Decision-Making, and Access to Justice in Environmental Matters (or Aarhus Convention 1998) is the principal internationally binding treaty that exclusively deals with issues of access. However, it is limited in the specific information it requires countries to publish: it requires state of the environment reports with supplementary materials (where feasible) and accurate summaries of environmental impact assessments to accompany primary documentation. In other areas, such as regulatory and policy formation and pollutant release and transfer registries, the
Convention focuses largely on making data available rather than making that information useful for citizens and understandable to individuals who may have limited understanding of such data (Haklay 2005). The Convention makes no mention of extending access to poor or minority communities, nor have subsequent rulings by the Aarhus Compliance Committee shown a tendency toward expansive interpretations of the Convention (Andrusevych, Alge, and Clemens 2008). Elsewhere, it has been pointed out that the Convention, as written, does not sufficiently address the information needs in the African context due to widespread illiteracy, low levels of awareness of rights and environmental issues, poor government infrastructure, and multiple languages (African Centre for Technology Studies et al. 2000).

A number of other existing environmental conventions and resolutions fail to specifically support the extension of access to the poor or to require additional steps to ensure that such procedures would be accessible for the poor. The United Nations Environment Programme's Draft Guidelines for the Development of National Legislation on Access to Information, Public Participation, and Access to Justice in Environmental Matters is also focused on a minimum level of availability of information.

Only the International Labour Organization Convention 169/1989 has assigned governments the duty of face-to-face consultation with communities, and even this is restricted to indigenous communities (Goodland 2008). Some have argued that rules like this could be extended in the context of free, prior, and informed consent processes in non-indigenous communities (Herbertson et al. 2009).

As countries and access proponents worldwide strive toward the goal of environmental democracy, we need to outline the characteristics of access that are useful for the poor. The research and experiences captured in this report aim to achieve this. 


\section{Findings: Barriers to Access for the Poor}

The case studies find that for access policies and procedures to serve the poor, they must focus on the usability as well as the availability of information and procedures. They highlight barriers of illiteracy, poor access to communication channels, high costs of access, personal and property risk, cultural context, and lack of official documentation. Positive action by government and other players is needed in order to overcome these barriers and make access effective for the poor.

Table 3 summarizes the cases analyzed and highlights the principal barriers to access in each case. From this, we are able to identify six major categories of barriers:

- Literacy

- Access to communication channels

- Cost

- Exposure to risk from participation

- Official documentation

- Cultural context

While each case shows that the poor face barriers to access, some of the cases demonstrate how governments and CSOs have overcome these barriers. This illustrates that a number of developing countries have already taken steps to fulfill the rights of the poor, even if it is on a piecemeal basis. Also important, the cases reveal that a general lack of access to information for all had a commensurately larger impact on access to information for the poor.

Each of the case studies TAI partners examined involve some sort of environmental harm or threat to the lives and livelihoods of individuals living in poverty. In some cases, access to information, public participation, and access to justice either played a part in reducing the environmental risk to individuals or helped them attain adequate remedy and redress for harms suffered. In the remainder of cases, individuals were unable to obtain access, and, in a number of cases, this lack of access led to deterioration of livelihood or environmental quality.

In some cases, the principal barrier to access for the poor was no different than that for the general population-information was simply unavailable, an environmental impact assessment or other participatory procedure was not carried out, or there was no forum to provide relief and remedy. In these cases, any potential improvements in access would benefit the entire population. We have not documented these barriers here, as they are well-documented elsewhere (see Foti et al. 2008 and Kravchenko and Bonine 2008 for longer discussions). For purposes of developing policy, it can be assumed that, generally speaking, the quality of access enjoyed by the public will be improved when a previously secret or closed decision can be made accessible.

Table 4 classifies and expands on the observed barriers that are particularly acute among people living in poverty and gives exemplary cases. We discuss each of these categories below. The legal framework underpinning the results in the four countries is outlined near the end of this section in Box 6 .

\subsection{Literacy}

Issues of literacy affect not only access to information, but also public participation and access to justice, both of which require access to information to be effective. The literacy needs of an individual attempting to exercise access rights varies across contexts, and some countries have taken progressive efforts to ensure that these issues are addressed. 
TABLE 3 SUMMARY OF CASE STUDIES

CASE AND YEAR OF EVENTS ASSESSED

\section{Paraguay}

Agrochemical spill in Capiata

2005

\section{Paraguay}

Worst wildfire in Paraguayan

history in Concepción and

San Pedro

2007

\section{Cameroon}

Water quality in Mendakwe

Village, Bamenda

2007

\section{Cameroon}

Forest revenue distribution

\section{Philippines}

Laguna Lake water quality

2006-2007

\section{Philippines}

Information on sustainable agriculture

\section{Sri Lanka}

Sethusamudran Ship Channel Project

2007

\section{SUMMARY}

\section{Environmental emergency}

Chemical spill threatened two towns, but government alerted local media and most human health impacts were avoided.
PRINCIPAL BARRIERS ENCOUNTERED

Access to information and communication technology

Access to information and

\section{Environmental emergenc}

National emergency team met during forest fires and established a hotline. While there was significant damage to land and property, most human health impacts were avoided due to a strong emergency warning system. After investigation, a new law on swidden practices passed.

communication technology

\section{Water quality monitoring}

A small village had no water quality information system established, despite legal requirements to do so. The case study found that government staff was unaware of the requirement. As a result, the village continues to have one of the highest percentages of water-borne diseases in its region.

\section{Facility-level}

The law on forest revenue states that villagers and local councils should receive a share of forest revenues (10 percent and 40 percent, respectively). There is, however, no transparency in the revenue management system at the local level (Morrison et al.). Consequently, mismanagement and corruption are rampant, with particularly serious effects on forest dwellers.

\section{Regular monitoring}

A mandate for information had been assigned to the Laguna Lake Development Authority, but members of the public turned to the Bureau of Fisheries and Aquatic Resources for information. While a brochure on environmental quality had been written, no effort had been made to disseminate the brochure to surrounding communities.

\section{Agricultural extension}

Agricultural extension programs are not presenting alternatives to conventional rice farming. Rice farmers receive information only on chemical-intensive farming despite a Department of Agriculture directive to educate farmers about a variety of techniques. Information not

\section{Emergency}

Sri Lanka

Regular flooding in Ratnapura 2007

Researchers found that the government had an adequate integrated management system. Leaflets and publications were given to the public on detection of flooding on a regular basis. During emergencies, communities were contacted by radio and three-wheelers. Written requests for information before and after floods do not always receive response due to weak government capacity (see Box 3).

\section{Transboundary}

India was to dredge a ship canal to the north of Sri Lanka (Adam's Bridge), affecting fishermen and ethnic groups. There was little precedent or legal basis for international EIA procedure or relevant access to information. As a result, poor residents of the region neither had access to information no a forum for participation

\begin{tabular}{|c|c|c|c|}
\hline \multirow{2}{*}{ 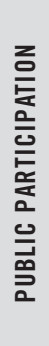 } & $\begin{array}{l}\text { Paraguay } \\
\text { Closure of the Caetura Garbage } \\
\text { Dump } \\
2007\end{array}$ & $\begin{array}{l}\text { Project/policy } \\
\text { Closure of the dump would cut off the livelihood of } 1200-1500 \text { residents and garbage pickers. The } \\
\text { municipal government led a number of consultations with residents and waste pickers with regard } \\
\text { to relocation and hazards. Most meetings were on-site and some subsidies were provided for travel } \\
\text { where needed. }\end{array}$ & $\begin{array}{l}\text { High costs } \\
\text { Foregone work } \\
\text { Time constraints } \\
\text { Cost of childcare }\end{array}$ \\
\hline & $\begin{array}{l}\text { Philippines } \\
\text { Public participation in the Biak- } \\
\text { na-Bato National Park } \\
2007\end{array}$ & $\begin{array}{l}\text { Policy, planning, budgets, and management } \\
\text { Agriculture and forest usage by the poor has gradually been translated into sustainable use with } \\
\text { participation. The recruitment and training of representatives from the community has meant that } \\
\text { the community has been able to voice its opinion over the land use within and adjacent to the park } \\
\text { (see Box 4). }\end{array}$ & $\begin{array}{l}\text { Costs - official fees, } \\
\text { travel, foregone work, time } \\
\text { Lack of technical capacity }\end{array}$ \\
\hline
\end{tabular}

Expectations about who has a "voice"

Water quality data not gathered

Corruption disseminated

Cost of travel Information not disseminated

Information not

disseminated

Access to information and communication technology Ability to understand technical content

\section{Information not}

disseminated

Access to information mechanisms unavailable

High costs

Foregone work

Time constraint travel, foregone work, time 
TABLE 3 SUMMARY OF CASE STUDIES (cont.)

\begin{tabular}{|c|c|c|c|}
\hline & $\begin{array}{l}\text { CASE AND YEAR OF } \\
\text { EVENTS ASSESSED }\end{array}$ & SUMMARY & $\begin{array}{l}\text { PRINCIPAL BARRIERS } \\
\text { ENCOUNTERED }\end{array}$ \\
\hline \multirow{4}{*}{ 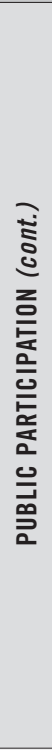 } & $\begin{array}{l}\text { Philippines } \\
\text { Management and use of } \\
\text { municipal fisheries and aquatic } \\
\text { resources, Southern Palawan } \\
2007\end{array}$ & $\begin{array}{l}\text { Policy formation } \\
\text { During the formation of a protected area in Southern Palawan, local fishermen were not consulted. } \\
\text { Partially as a result, these communities were deprived of livelihood and alternatives to fishing. In the } \\
\text { meantime, a pearl farm was granted a concession in the same area. }\end{array}$ & $\begin{array}{l}\text { Policy made without } \\
\text { participation } \\
\text { Expectations about who } \\
\text { has a "voice" }\end{array}$ \\
\hline & $\begin{array}{l}\text { Sri Lanka } \\
\text { Magnetite mining in Buttala } \\
2007\end{array}$ & $\begin{array}{l}\text { Project decision } \\
\text { An exploration license and environmental impact assessment for a magnetite mine, processing } \\
\text { plant, and export harbor were undertaken, and general participation was good, but, according to } \\
\text { researchers, few of the poor residents in the area of immediate impact had heard anything about the } \\
\text { decision-making process. }\end{array}$ & $\begin{array}{l}\text { Access to information and } \\
\text { communication technology }\end{array}$ \\
\hline & $\begin{array}{l}\text { Sri Lanka } \\
\text { Garbage dumping in } \\
\text { Pothuwilkumbura } \\
2007\end{array}$ & $\begin{array}{l}\text { Project decision } \\
\text { In Pothuwilkumbura, a landfill with an encroaching shantytown has not undergone an environmental } \\
\text { impact assessment. While the city made some decision-making processes public, these have been } \\
\text { almost entirely through local newspapers, and no formal public participation has taken place with } \\
\text { the surrounding communities. }\end{array}$ & $\begin{array}{l}\text { Public participation } \\
\text { inaccessible to the poor } \\
\text { Access to information and } \\
\text { communication technology }\end{array}$ \\
\hline & $\begin{array}{l}\text { Sri Lanka } \\
\text { Kandy-Colombo Expressway } \\
2004\end{array}$ & $\begin{array}{l}\text { Project decision } \\
\text { Construction of an expressway cut across four districts. While an initial route was planned with } \\
\text { adequate consultation, a second route was chosen, and locals—including many poor rural } \\
\text { residents—-were displaced without adequate discussion. }\end{array}$ & $\begin{array}{l}\text { Plans were changed after } \\
\text { public participation } \\
\text { Newly affected } \\
\text { communities not } \\
\text { consulted }\end{array}$ \\
\hline \multirow{7}{*}{ 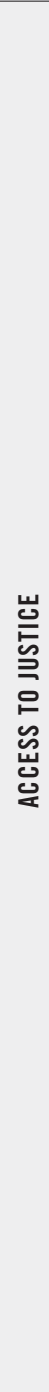 } & $\begin{array}{l}\text { Cameroon } \\
\text { Farmer-grazer dispute in Wum } \\
2008\end{array}$ & $\begin{array}{l}\text { Other } \\
\text { Law provides for a Farmer-Grazer Commission, but land was transferred to grazers illegally, putting } \\
\text { local farmers at a disadvantage. While the tribunal was supposed to be impartial, its decisions were } \\
\text { regularly compromised as a result of corruption. }\end{array}$ & Corruption \\
\hline & $\begin{array}{l}\text { Paraguay } \\
\text { Rincon-i seed and agrochemical } \\
\text { spill } \\
2004\end{array}$ & $\begin{array}{l}\text { Environmental harm } \\
\text { A spill resulted in the largest contamination in national history, which affected local communities } \\
\text { and agricultural workers. The ombudsman brought suit in a criminal case, resulting in the first } \\
\text { environmental crime case successfully prosecuted against a multinational company in Paraguay. } \\
\text { State representation made it possible for justice mechanisms to be used. }\end{array}$ & $\begin{array}{l}\text { Costs of bringing a case } \\
\text { were high }\end{array}$ \\
\hline & $\begin{array}{l}\text { Paraguay } \\
\text { Illegal traffic of the threatened } \\
\text { Palo Santo species } \\
\text { 2002-present }\end{array}$ & $\begin{array}{l}\text { Environmental harm } \\
\text { The Palo Santo is a protected tree that was being exploited in a protected area of Ayoreo } \\
\text { Totobiegosode. The largely indigenous community was divided over protection versus exploitation. } \\
\text { The ombudsman carried out an investigation and covered the costs of a trial, finding individuals } \\
\text { guilty of illegal traffic of the wood (see Box 5). }\end{array}$ & $\begin{array}{l}\text { Citizens enforcing the rule } \\
\text { were put at personal risk } \\
\text { High costs of trial }\end{array}$ \\
\hline & $\begin{array}{l}\text { Paraguay } \\
\text { Pollution of the Parana River by } \\
\text { Argentine pulp mills } \\
2006\end{array}$ & $\begin{array}{l}\text { Environmental harm } \\
\text { The Parana River forms part of the border between Argentina and Paraguay. Operation of pulp mills } \\
\text { along the river resulted in severe degradation of environmental quality for citizens living near the } \\
\text { river. However, no forum existed which could hear the grievances of affected communities, and no } \\
\text { case could be brought. }\end{array}$ & $\begin{array}{l}\text { No justice mechanism } \\
\text { available }\end{array}$ \\
\hline & $\begin{array}{l}\text { Philippines } \\
\text { La Bugal Bu'Laan Association } \\
\text { case against mining law } \\
2004\end{array}$ & $\begin{array}{l}\text { Environmental harm } \\
\text { A community in southwest Mindanao wanted to deny the permit of a foreign mining company. The } \\
\text { Supreme Court, in this case, overturned a previously existing ban on foreign investment in mining, } \\
\text { resulting in a degraded environment for the community. To some extent, lack of success in the case } \\
\text { can be attributed to the difficulties the community had in reaching the Court. The pleadings and } \\
\text { hearings were distant (in Manila), there were high costs of securing and submitting documentation, } \\
\text { petitioners in remote parts of the island found it difficult to communicate, and long delays made the } \\
\text { financial burden difficult to bear. }\end{array}$ & $\begin{array}{l}\text { High costs of travel to } \\
\text { prosecute case } \\
\text { Weak ability of citizens } \\
\text { to understand technical } \\
\text { content }\end{array}$ \\
\hline & $\begin{array}{l}\text { Philippines } \\
\text { Marcopper Mine damage } \\
\text { compensation claims of Boac } \\
\text { River disaster } \\
1996 \text { (orig. incident) }\end{array}$ & $\begin{array}{l}\text { Environmental harm } \\
\text { Victims of mine disaster sought recompense for environmental harm and loss of life. During the } \\
\text { negotiation of the mining permit, individuals and communities were locked into using a dispute } \\
\text { resolution mechanism that used delay tactics and conditionalities to deny repayment to poor } \\
\text { families. One common barrier was the denial of payment or under-compensation because poor } \\
\text { individuals could not provide proof of income tax or property ownership. }\end{array}$ & $\begin{array}{l}\text { High burden of proof } \\
\text { placed on farmers } \\
\text { Lack of choice in justice } \\
\text { forum }\end{array}$ \\
\hline & $\begin{array}{l}\text { Sri Lanka } \\
\text { Sand mining at Dederu 0ya } \\
2007\end{array}$ & $\begin{array}{l}\text { Environmental harm } \\
\text { Too much dredging of sand resulted in a loss of agricultural land for poor farmers along the Dederu } \\
\text { Oya, a river in Sri Lanka. Some legal aid was available for this case as it was brought in under a } \\
\text { fundamental rights case. While multiple forums were available, one (the Supreme Court) is costly } \\
\text { and slow, while the other (the Human Rights Commission) is relatively efficient, but its rulings are } \\
\text { non-binding. }\end{array}$ & $\begin{array}{l}\text { Forums either have high } \\
\text { costs or are ineffective }\end{array}$ \\
\hline
\end{tabular}




\section{TABLE 4 ACUTE BARRIERS FACING THE POOR}

\begin{tabular}{|c|c|}
\hline BARRIER & EXEMPLARY CASES \\
\hline LITERACY & \\
\hline basic reading skills & $\begin{array}{l}\text { Cameroon - Farmer-grazer dispute in } \\
\text { Wum }\end{array}$ \\
\hline $\begin{array}{c}\text { ability to understand technical } \\
\text { content }\end{array}$ & $\begin{array}{l}\text { Philippines - La Bugal Bu'Laan } \\
\text { Sri Lanka - Association Case against } \\
\text { mining law }\end{array}$ \\
\hline language & Garbage dumping in Pothuwilkumbura \\
\hline
\end{tabular}

\section{ACCESS TO COMMUNICATION CHANNELS}

access to information and

communication technology

(information technology such

as Internet, papers, television, radio, SMS)

COST

official fees

travel

foregone work

time constraints

cost of childcare

corruption

Sri Lanka - Regular flooding in
Ratnapura

Philippines - Marcopper Mine damage compensation claims

Philippines - Public participation in the Biak-na-Bato National Park; Laguna Lake water quality

Paraguay - Closure of the Caetura Garbage Dump

Paraguay - Closure of the Caetura Garbage Dump

Paraguay - Closure of the Caetura Garbage Dump

Cameroon - Forest revenue distribution; Farmer-grazer dispute in Wum

\section{EXPOSURE TO RISK FROM PARTICIPATING}

personal risk (physical or psychological intimidation)

Paraguay - Illegal traffic of Palo Santo threatened species

property risk (threat of expropriation, burglary, etc. $)^{a}$

\section{LACK OF OFFICIAL DOCUMENTATION}

lack of legal identity and narrow standing ${ }^{a}$

burden of proof

\section{CULTURAL CONTEXT}

expectations about who has a "voice"

meaningfulness of participation

Philippines - Marcopper Mine damage compensation claims; Paraguay Illegal traffic in Palo Santo

Cameroon - Water quality in Mendakwe Village, Bamenda

Sri Lanka - Kandy-Colombo Expressway

a. While the case studies did not mention these risks, a review of related literature has shown them to be significant barriers to access. See the individual entries for each barrier in the main text for references.

\section{LANGUAGE BARRIERS}

At the most basic level, a person must be able to speak the language in which information is transmitted. Yet many decisions are made in official languages. As a result, individuals who do not speak the official language and do not have a ready and capable translator have little chance of understanding decision-making processes. This problem is especially acute in linguistically fragmented countries (African Centre for Technology Studies 2000). One of the public participation cases from Sri Lanka, which dealt with the construction of an expressway from Kandy to Colombo, provides an example of how officials can address this challenge. In this case, an environmental impact assessment originally written in English was translated into local languages.

\section{BASIC READING SKILLS}

Even when language is not an issue, ability to read basic information may be a problem. Evidence from the farmer-grazer dispute in Wum, Cameroon, and from the Marcopper Mining case in Philippines suggests that individuals were unable to use justice forums because they did not understand basic procedures. In these cases, efforts to ensure that the public - many of whom had limited reading ability—could understand forum procedures would have required communication through spoken media, such as radio.

\section{TECHNICAL READING SKILLS}

Even fully literate populations may find technical information a barrier to enjoyment of access rights. Box 3 provides an example of good practice, where the Sri Lankan government ensured that emergency warning systems matched the literacy and technology levels of local communities and that technical data gathering (e.g., rainfall monitoring) was simplified. Increasingly, at least in environmental impact assessments, non-technical, but accurate summaries are a widely accepted best practice. Indeed, this is one of the most inclusive provisions in the Aarhus Convention and in many national laws.

\subsection{Access to communication channels}

Despite the rapid advance and dissemination of information and communications technology (ICT), which includes internet, television, digital radio, and text messaging many poor communities live beyond its reach. In developing countries in 2007, only 17 of 100 individuals had access to the Internet (compared to 22 of 100 globally), and 45 of 100 had access to mobile phones (International Telecommunication Union 2007). Little access to communication channels detracts from successful implementation of programs for access to information, public participation, and access to justice. In some cases, the enthusiasm over online forms of governance (including participation enhanced by 
ICTs) may be misplaced. While access to technology such as mobile phones is spreading, such access is not necessarily conducive to the complex interactions required for decision-making related to the environment, such as project siting. Additionally, interference with established media channels can mean that poor individuals-already hard pressed to locate information, regardless of quality-find themselves unable to access reliable and accurate information. The Sri Lankan case in Box 3 suggests that more traditional forms of communication (in this case word of mouth, radio, and three-wheeled taxis) may remain the most effective means of communication.

\subsection{High costs}

A number of factors raise the costs of accessing information, participation in decision-making, and access to justice. Many special costs are involved in access to justice, which is dealt with separately below.

\section{TRAVEL}

Members of poor communities regularly raised the cost of travel as a barrier to their participation in environmental decision-making. People working in the Caetura garbage dump in Paraguay, for example, were very willing to participate in on-site public consultations, but many found it impossible to attend meetings held in the center of the city. Box 4 tells the story of one Philippine community that was able to contribute to official decisions-in part because the government subsidized travel to and from major meetings.

\section{FOREGONE WORK, CHILDCARE, AND TIME CONSTRAINTS} Another major cost of participating in, or requesting information about, environmental decision -making, is that poor individuals may need to forego work to do so, especially if participatory events take place during the formal workday. This is especially significant for women who may have substantial domestic labor responsibilities. Without opportunities for childcare, or the ability to participate at a variety of times, public participation can be difficult (Bryant and Kappaz 2005). None of the cases studied indicated particular efforts on the part of organizing agencies to enable female participation or to ensure that important environmental health data reached women, who are most often the primary caretakers.

\section{BOX 3 REgULAR FLOODING IN RATNAPURA}

The Ratnapura District is located in central Sri Lanka and is prone to floods and landslides. Regular flooding causes extensive damage to lives and property in the district, which is home to the third largest population in Sri Lanka living below the poverty line. The TAl partner study demonstrated little active discrimination on the part of government agencies toward the poor and found a number of model activities for prevention and management that reach poor communities.

Under the Sri Lanka Disaster Management Act No.13 of 2005, the National Council for Disaster Management has a legal duty to ensure adequate publicity for the National Disaster Management Plan and Emergency Operation Plan and to promote public awareness campaigns relating to disaster management. The case study showed that in 2005 the Emergency Operations Centre speedily implemented such a Disaster Preparedness and Response Plan. According to the researchers, "a proactive approach toward information dissemination was more visible in respect of this emergency situation than in the other case types that were studied."

\section{REPORT FINDINGS}

The Council's integrated information management system was adequate in scope and quality. The Emergency Operations Centre collects daily information from relevant departments and, in the event of a flood threat, issues timely evacuation warnings by vehicle and a public announcement system. Leaflets and publications are also issued to the public. New rainfall gauges have been installed and the public, including poor communities, are to receive training in how to read them.

Researchers were told that the official focus is on all inhabitants of flood prone areas and not specifically the poor. Flood warnings are given in timely fashion by a ground force of three-wheelers and motorcycles that can access remote areas and are also circulated through the media and the police. Apart from flood warnings and instructions on how to read rain gauges, information has to be sought from the relevant agency.

The ultimate effect was that most relevant information reached the public, including the poor, in time. The researchers' sole criticism was that the program was not targeted toward flood prevention or the reduction of individual behaviors contributing to flood-prone conditions. 


\section{BOX 4 PARTICIPATORY MANAGEMENT IN BIAK-NA-BATO NATIONAL PARK}

The Philippine law on the establishment of national protected areas explicitly acknowledges that many poor people (and, in some areas, communities of indigenous peoples) have either settled within park boundaries or use park resources to support livelihoods including slash-and-burn agriculture and the gathering of timber and nontimber products.

The law therefore established a protected area management board (PAMB) to engage poor users in park management and to improve a sense of community ownership for park protection. Members of people's organizations (PO) or local non-governmental organizations must be included on the PAMB and in its decision-making processes. As a result, in the case of the Biak-na-Bato National Park, participation by the poor in park management seems to have become the norm.

Biak-na-Bato National Park is both a natural and historic treasure, famous for its caves and its role in the Philippine War of Independence against Spain. A proposal to intensively mine land that had formerly been within park borders made national news, and the involvement of members of the poor community on the PAMB made a critical difference in resisting the mining project.

According to interviews conducted, the PO representatives on the board believe that they participate substantially in park management and government representatives on the board take their participation seriously. A serious shortcoming, however, is the lack of capacity building for the PO members, who have no experience or training in park management. The government agency overseeing the PAMB, the Department of Environment and Natural Resources (DENR), determined that training provided by a CSO to the PO representatives has been sufficient. According to the Philippine research team, however, "such training [has] been largely rudimentary and it would help the PAMB members if they could get specific training on how to manage the important strategic issues involved in protecting the park."

PO representatives on the PAMB felt that they were involved in all the decisions made so far, because they regularly attended all meetings. Promisingly, they also believed that being poor farmers and settlers did not put them at a disadvantage in terms of participation. The PAMB Secretariat, which is made up of staff from the DENR provincial office, also provided all members with documents and information in an adequate and timely fashion.

P0 representatives pointed out that board participation had inspired them to advocate against mining in the former park area, and they were able to effectively represent the desire of neighboring communities that the government return the park to its original size and status.

Despite this meaningful level of participation in park management, both law and practice could benefit from some improvement. For example, information regarding the PAMB's processes and decisions was not generally made public. The PAMB's records were kept in the Secretariat's office in Malolos City, whereas the PO representatives interviewed would prefer records to be made available to the public after each board meeting. Another concern was bearing the upfront cost of getting to the meeting venue, since government travel allowances would arrive weeks after the meeting. This sometimes prevented PO members from attending, suggesting that travel subsidies should be made available before or at the time of participatory meetings.

\section{OFFICIAL FEES}

Fees for official information, even when nominal to members of the middle class, can be prohibitive for the poor. Best practice dictates that accessing information should be cost-free (Article 19 2010). For example, the Sri Lankan team found that the government did not charge for information. The Philippine government waives court fees for the indigent if they can prove "pauper" status.

\section{CORRUPTION}

Corruption, the use of public office for private gain, is a complex problem beyond the scope of this report. Nonetheless, in several of the cases, corruption rendered decision-making processes and justice forums useless. According to the case studies, the poor are less able to accommodate or resist a corrupt official or institution and therefore decisions are rarely made in their favor under such circumstances. The high costs of a bribe can drive poor individuals away from seeking justice at all or may erode trust in the ability of the institution to deliver a fair decision.

\subsection{Exposure to risk from participating}

Individuals can face risks to person and property when they participate in public forums. Threats of physical or psychological intimidation were present, for example, in the case highlighted in Box 5. Illegal threats can be directed at poor individuals, officials who assist them in obtaining information, or organizations that seek to work with poor individuals (Kravchenko and Bonine 2008). 


\section{BOX 5 ILLEGAL TIMBER TRADE IN PARAGUAY}

The Paraguayan research team evaluated historically significant cases for their assessment of access rights. The case study highlighted here represented a milestone in which a state attorney brought the first case for an environmental crime ever prosecuted in the country. The outcome is relevant to this report for two reasons: the involvement of a marginalized indigenous community and the unique support (among the countries surveyed) that Paraguay's government has given to providing access to justice.

The Palo Santo tree is on the red list of the IUCN Threatened Species, is officially declared in danger of extinction, and has been under restricted use since 1993. This has increased its value and the precious wood is now even more coveted, creating a thriving black market.

A large part of the Palo Santo reserve is located in the Paraguayan Chaco, in a protected area of the indigenous group Ayoreo Totobiegosode. The illegal traffic of Palo Santo has created a great deal of conflict within the Ayoreo, including physical threats and intimidation. Roughly half of the Ayoreo participate in the traffic and illegal trade of Palo Santo, and the other half is completely against it. Those who cut the trees and sell the wood do it in exchange for food, cash, and caña (an alcoholic drink made from sugarcane).

Prior to the ongoing legal case studied, there has never been successful prosecution of Palo Santo trafficking. It has been particularly difficult for the state attorneys to find sufficient evidence to try traffickers. The cost of evidence gathering is a key barrier to enforcing environmental laws. This Paraguayan case suggests that —at least where environmental violations are written into the criminal code - state-supported attorneys can aid in enforcing those laws and help members of the community who are in favor of preserving environmental resources.

Poor individuals may also face a threat to property, including a threat of expropriation or burglary should they leave their home for extended periods of time, including while exercising their access rights. While no case in our review demonstrated this exact problem, it has been cited in other literature as an obstacle to obtaining information, participation, and the use of justice forums (Barendrecht and van Nispen 2008; Field 2007; Excell and Thompson forthcoming).

\subsection{Lack of documentation}

For many of the poor, documenting their status as individuals entitled to access is difficult or impossible. This lack of documented status can render access-to justice in particular-out of reach.

\section{LACK OF IDENTITY AND STANDING}

Lack of legal identity is a common barrier to exercise of access. In order to access justice forums, individuals must have appropriate identification. In addition, basic identification such as documentation of citizenship and residence may be necessary to conduct business transactions or use other government services. Some countries, such as Canada, require official proof of residence in order to request information (Legault 2009). While none of our cases directly feature the specific problem of identity, it has been documented extensively in the UNDP Commission for Legal Empowerment for the Poor report, Making the Law Work for Everyone (2008).

A related problem is that of legal standing. One of the biggest challenges individuals may face is showing that they are directly affected by an environmental harm or poor enforcement of a law. This is not only limited to justice forums, but also affects the ability of individuals to participate. Some jurisdictions require individuals to demonstrate that they are likely to be "affected" by the outcome of a decision in order to participate in environmental impact assessment proceedings. In Madhya Pradesh, India, for example, such proof requires a written note by a village headman stating that an individual will be affected by a potential project (Kuldna 2009). Obtaining this proof may be an insurmountable barrier for the poorest of the poor, as elites at the village level may deem participation by lower-status individuals inappropriate or may block participation that runs counter to their interests.

\section{BURDEN OF PROOF}

Burden of proof is an issue unique to access to justice. Inadequate property registration and lack of property tax records caused problems for the poor in the Philippine Marcopper Mining Disaster. After effluents from the Marcopper Mine destroyed significant amounts of land and livestock in 1996, local farmers went to make claims at an alternative dispute resolution forum that had been established for communities living near the mining site. However, because few farmers were able to document that they grazed their cattle in the affected 
area, or that they had owned a particular number of cattle, they were unable to claim damages. As a result, many individuals have gone without recompense for over 12 years. This example suggests the need for better systems of property registration as well as justice institutions prepared to deal with the reality that many of the poor do not have adequate property records.

\subsection{Cultural context}

While many of the issues dealt with here might lend themselves to rather technical solutions, some might require deeper cultural change or change in attitudes and expectations. As a result, these issues do not necessarily have easy or quick solutions.

\section{EXPECTATIONS ABOUT WHO HAS A VOICE}

Social status greatly affects the willingness of individuals to solicit information, to participate in public conversations, or to challenge someone in a justice forum. Additionally, individuals may not be invited to participate, or are assumed to be too uneducated to contribute meaningfully to decision-making (Cooke and Kothari 2002). The exact nature of such discrimination varies by context, race, caste, gender, social class, language, immigrant status, or age and can be a subtle or overt justification for exclusion. In the Philippine case, "Management and use of municipal fisheries and aquatic resources, Southern Palawan," officials ignored requirements to consult the politically weak villagers living inside the area of the fisheries.

\section{BOX 6 FINDINGS ON LAW AND ACCESS FOR THE POOR}

The legal and policy framework around access rights plays an important role in addressing the barriers outlined above. Strong frameworks give a mandate to government officers seeking to carry out access activities and establish lines of answerability and accountability. A discussion of the legal background for access rights can be found in an online annex at http://www.accessinitiative.org/ poverty/node/1086. A number of basic observations can be made about the law in the four countries studied:

- There are relatively few laws that specifically provide for special actions for access for the poor. Laws on legal aid and, in the United States, an Executive Order on "Environmental Justice" (see Box 7) are notable exceptions.

- We found no evidence of laws in our sample that would prohibit the development of laws or policies that required special actions for poorer communities.

- Where general laws on access were not in place, there was no example within our cases of special actions made to ensure that the poor had access to information, public participation, and access to justice.

Cameroon's constitution and laws on the environment demonstrate these general observations. In particular, Cameroon's laws have the potential to progressively involve the poor through strong access rights, but, at present, lack some of the strongest provisions required to put such rights in place.
The Cameroon constitution guarantees the right to a healthy environment and creates a corresponding duty for the state to ensure the protection and improvement of the environment. The document also appends the Universal Declaration of Human Rights. This provides for protection against discrimination by the state as well as a fundamental right to information.

At the level of statute, there are piecemeal efforts in Cameroon at environmental preservation and access rights. The right to environmental information provided by the 1996 Environmental Management Law (Law $N^{\circ}$ 96/12) requires all citizens to be informed of the negative effects of harmful activities on man, health, and the environment as well as on the measures taken to prevent and compensate for these effects. The most recent Decree on Environmental Impact Assessment (Decree № 2005/0577/PM) is supposed to ensure that members of the public are fully informed and have the ability to participate, but does not require the consultation to be at an early phase.

Perhaps as a result of weak laws and, to a further extent, weak compliance with and enforcement of existing laws, practice on the ground varies widely. Case studies in this report show that, while not expressly prohibitive, Cameroon's legal framework exemplifies the lack of comprehensive instruments such as a freedom of information act and a general notice and comment law (e.g., an administrative procedures act) to ensure that abstract principles in the constitution can become regularly applied practices. 


\section{MEANINGFULNESS OF PARTICIPATION}

Individuals are motivated to participate when they have a chance at influencing the outcome. In short, their participation is meaningful. One useful definition of meaningful participation is that it occurs early enough in a process to influence the outcome, and that officials have a responsibility to justify their course of action in light of public participation (Webler, Tuler, and Krueger 2002). The Kandy-Colombo Expressway case from Sri
Lanka is an example of exclusion due to poor timing of participation. Some villagers were consulted at the outset of the project, but, after project plans changed those most affected were unable to influence the outcome of the actual project design. The culture of "tick-box" participation is detrimental to the quality of participation, as it forgoes many benefits of participation such as increased legitimacy and incorporating a wider range of cultural values. 


\section{3 Recommendations: Leveling the Access Playing Field}

As outlined in the first section of this report, recent decades have seen the three pillars of access to information, public participation, and access to justice become increasingly accepted principles of environmental governance. The Access Initiative's review of decisions affecting the environment in four countries showed that while existing standards are essential to making access available, they are inadequate for delivering access to the poor. The case studies showed that data is nowhere near as important as information, that participation is meaningful only as much as it is inclusive and accountable, and that the opportunity to influence decisions is intrinsically connected to the ability to do so.

To this end, we propose a set of policy recommendations - an action agenda to "level the access playing field." While governments will own the balance of the work in implementation, civil society and donors can play roles as key drivers of reform. In this section, we flesh out policies for more inclusive access for poor communities and suggest a series of steps to institutionalize such policies.

\subsection{Eight policy responses for more inclusive access}

To address the barriers examined in the previous section, we have developed a set of policy responses. The list is not intended to be complete, but rather a starting point or action agenda for reform. Table 5 presents the barriers found in Section 2 and addresses each barrier individually. Below, we make recommendations on implementing each policy response, based on positive examples from our case studies and elsewhere.
POLICY RESPONSE 1: IDENTIFY THE POOR AND ESTABLISH THRESHOLDS FOR ENHANCED ACCESS In determining strategies to strengthen access, identify the poor with a stake in the outcomes of decisions. Dedicate resources to reach out to these individuals and communities. Establish clear guidance for officials around thresholds to provide enhanced access.

A critical step in extending access to the poor will be to take steps to locate them in order to target appropriate interventions, including tailored information and enhanced participation. In some cases, countries lack adequate census data to identify where poor communities are-be they ethnic minorities, linguistic minorities, or migrants. In other countries, agencies operating in a context of finite resources may not have clearly defined guidelines or "thresholds" for when they should target special interventions to improve the quality of access for the poor. In the case of the United States (see Box 7), a number of states have set thresholds for enhanced participation of poor and ethnic minority communities in decision-making for the environment. As an example, the U.S. State of Massachusetts has defined "environmental justice" (EJ) communities as:

EJ Populations are those segments of the population that EOEA [Executive Office of Environmental Affairs] has determined to be most at risk of being unaware of or unable to participate in environmental decision-making or to gain access to state environmental resources. They are defined as neighborhoods (U.S. Census Bureau census block groups) that meet one or more of the following criteria:

1. The median annual household income is at or below 65 percent of the statewide median income for Massachusetts; or 
TABLE 5 BARRIERS TO ACCESS FOR THE POOR AND POLICY RESPONSES

\section{BARRIER}

LACK OF LEGAL THRESHOLDS FOR ENHANCED ENGAGEMENT

LITERACY

basic reading skills

ability to understand technical content

language

ACCESS TO COMMUNICATION CHANNELS

poor physical access to information technology such as Internet, papers, television, radio, SMS

COST

official fees

travel

foregone work

time constraints

cost of childcare

corruption

\section{EXPOSURE TO RISK FROM PARTICIPATING}

personal risk (physical or psychological intimidation)

property risk (threat of expropriation, burglary, etc.)

OFFICIAL DOCUMENTATION

lack of legal identity

burden of proof

\section{CULTURAL CONTEXT}

expectations about who has a "voice"

meaningfulness of participation

\section{POLICY RESPONSE}

1. Identify the poor and establish thresholds for enhanced access

2. Use the appropriate form: ensure that information around decisions and opportunities to influence decisions for the environment matches the technica understanding, literacy levels, and native languages of the poor

3. Use the appropriate channels: ensure that information around decisions and opportunities to influence decisions for the environment is communicated through channels used by the poor

4. Reduce costs: remove barriers, reduce official fees, and provide subsidies for participation

5. Defend the individuals and organizations that promote access

6. Remove legal barriers of standing and evidence

7. Build capacity and raise awareness

8. Make the voice of the poor influential
2. 25 percent of the residents are minority; or

3. 25 percent of the residents are foreign born, or

4. 25 percent of the residents are lacking English language proficiency. (Massachusetts Executive Office of Environmental Affairs 2002; emphasis added)

Of course, such standards are tailored to the particular circumstances of Massachusetts. Many countries already have adequate census data in place to set similar thresholds for action. At other times, information sharing between agencies is required, as such information may not be held by an environmental agency but by public health, education, or welfare agencies. In either case, officials require clear guidance on what socioeconomic characteristics they should look for and adequate data to ensure that decision-makers know who will be affected. These thresholds will necessarily vary by context.

In some countries, such data does not exist or such criteria might not fit the exact circumstances. In these countries, more informal measures or coordination with CSOs may be necessary to locate the poor. Similarly, such identification will be necessary to ensure that capacity-building and public education campaigns are targeted at impacted communities. In those instances where the majority of the affected population is poor, individuals facilitating participation should devote a greater share of resources to ensuring that information is fully accessible to citizens in the area.

\section{POLICY RESPONSE 2: USE THE RIGHT FORM TO COMMUNICATE}

To the greatest extent possible, make sure that environmental information made available is useful and useable in informing decisions.

In general, the public benefits from environmental information that is provided in accessible and actionable formats. The case studies identified problems related to basic reading skills, difficulty with technical content, and issues of language that can be common among poor communities. Deficits in basic reading skills can be addressed by ensuring that notices to comment and opportunities to participate are provided through visual or spoken media such as posters, radio, or meetings of civic associations and local government. Similarly, simple report cards on environmental quality 


\section{BOX 7 CAN THE UNITED STATES SERVE AS AN EXAMPLE FOR DEVELOPING COUNTRIES?}

At present, the United States is one of a very few countries with a directive requiring specific efforts to inform and involve poor and minority communities in "enhanced participation" in agency decisions that affect the environment (South Africa, South Korea, and the European Union's Roma Directive also provide some basis for improving access for the poor in decisions affecting the environment). Though implementation of the law has been flawed, it is one possible starting point for a framework law to enable people living in poverty to have a voice in decisions for the environment.

In 1994, U.S. President Bill Clinton issued Executive Order (E0) 12898, Federal Actions to Address Environmental Justice in Minority Populations and Low-Income Populations. The regulation serves as a case study of a framework law on public participation targeting poor populations.

\section{The Requirements of the Law}

EO 12898 came on the heels of a variety of studies showing that toxic waste sites were disproportionately located near low-income and minority populations in U.S. cities. The regulation established the Interagency Working Group on Environmental Justice to design a set of operational guidelines for federal agencies. It also mandated that federal agencies develop strategies to:

- improve and ensure enforcement of environmental laws in poor and minority communities;

- foster greater public participation; and

- improve information collection on environmental health and resource consumption in poor and minority communities.
An accompanying presidential memorandum mandated the incorporation of new practices into already existing environmental impact assessment procedures. This required federal agencies to:

- analyze the particular effects of federal actions on poor and minority communities;

- address the negative effects of mitigation procedures outlined in environmental assessments; and

- improve accessibility to the public through "enhanced participation."

The Council on Environmental Quality (the executive authority responsible for issuing EIA guidelines and regulations) also encouraged agencies to go beyond the regular requirements of the Notice of Intent for a Proposed Action by notifying and working with the following organizations to enable enhanced participation:

- ethnic radio stations;

- religious institutions;

- local newspapers (weeklies and ethnic press);

- civic associations (such as civil rights organizations);

- minority business associations;

- environmental groups;

- homeowners' associations and neighborhood watch groups;

- federal, state, local, and tribal governments;

- rural cooperatives;

- senior citizen associations; and

- health agencies (adapted from Bass 1998).

box continued next page can be helpful, with color coding or numerical or letter grades on publicly displayed signposts.

Technical content may be simplified in a number of ways. First, many countries have made strides in providing simplified, but accurate versions of background documents on environmental impacts. This has been especially true of environmental impact assessments, and such requirements have been mainstreamed into practices internationally through the Aarhus Convention and in the practices of multilateral development banks. This critical practice should be universalized and integrated into other processes such as regulatory reform. Similarly, simplified guides should be prepared on participation in environmental impact assessments and responsibility for reporting incidents such as harmful material spills. Finally, some countries have the potential to reach out (at least in urban areas) to the poor through intermediaries-libraries, schools, media, or scientific educators-who can help explain technical content. Such innovative partnerships can bring understandable information to those who might otherwise become frustrated with the technicalities of environmental information.

When officials are deciding how to spend scarce resources on access to information and participation, a priority should be placed on clarity and precision over comprehensiveness. For example, a government monitoring toxic emissions from a dump should first focus resources on ensuring that the affected communities understand the danger of toxic materials in their neighborhood, know how to avoid harm, if possible, and, if not, can identify ways to work with others to reduce the harm. In many situations, this approach should be a higher priority than the international best practice of 


\section{Implementation Challenges}

The difficulty experienced in implementing E0 12898 sheds light on the potential challenges involved in creating a framework that attempts to address both procedural and substantive inequalities in environmental quality.

Lack of methodologies: There are, as yet, no established or uniform means of measuring the unequal environmental impacts of project and policy decisions. While there are a variety of social science methods available, the appropriate census taking and scientific protocols to estimate exposure to risks are under development.

Poor funding: Environmental Protection Agency offices (air, water, and land) have had difficulty funding and maintaining the staff to ensure equity in decisions with environmental consequences. Some of this is due to a lack of available resources and some is due to an absence of political will.

Reviewability: The presidential memorandum exempted the regulation from any sort of legal action, stating that it, "is not intended to create any right, benefit, or trust responsibility, substantive or procedural, enforceable by law or by equity by a party against the United States, its agencies, its officers or any person." Because of this, the Order is arguably not reviewable by any court. Although a number of cases have been brought to various courts, plaintiffs invoking E0 12898 have been repeatedly rebuffed on these grounds (ACORN v. U.S.
Army Corps of Engineers, 2000 U.S. Dist.; Morongo Band of Mission Indians v. Federal Aviation Administration, 1998 9th Circuit; Sur Contra La Contaminacion, v. EPA, 1st Cir. 2000; Citizens Concerned about Jet Noise v. Dalton, E.D. 1998 Va.) (Gerrard 2000). The majority of successful environmental justice lawsuits have won on grounds related to the Equal Protection Clause of the Civil Rights Act of 1964, a law dealing with discrimination and endangerment rather than environmental procedure.

Legitimacy: Because the Order came from the Executive, it has neither the full force nor the legitimacy of an act of Congress. Ideally, a framework law for access rights in environmental matters would derive from legislative action in order to increase both legitimacy and enforceability (adapted from Rosenbaum 2008).

The U.S. case suggests that some basic problems of implementing such an order still exist, even for a rich country with a strong history of participation. In particular, it has proven difficult to create mechanisms to enforce environmental justice orders and to coordinate agency actions to address environmental justice issues. Developing country governments can, however, adopt the basic legal mechanisms from the U.S. model, such as enhanced participation and improved access to information, and scale this engagement to the resources, scope, and impact of their own projects. developing a long list of chemicals that communities may be exposed to.

Finally, language is an issue, especially in countries with significant linguistic minorities. Most countries have one or two languages that the middle classes speak in official interactions. At a minimum, governments can ensure that key documents (for example, environmental reports, environmental impact assessments, regulatory changes, and court decisions) are translated into these major languages. Additionally, simplified summaries can be translated into local languages of affected communities, and interpreters should be on hand for public participation to ensure that the public understands the information and options transmitted to them and that their opinions may be suitably recorded and addressed. The role of interpreters is especially important in cases where there are few literate speakers of a language.

\section{POLICY RESPONSE 3: USE THE RIGHT CHANNELS TO COMMUNICATE}

Communicate information through culturally appropriate channels_radio, bulletin boards, or religious institutions, for example. Where information and communication technology is rare or unavailable, use low-tech solutions to spread information about the environment and opportunities to influence decisions.

In many situations, participation is highly dependent on information and communication technology. In cases where this reliance is absolutely necessary, it is critical that the poor have access to electronic means of communication, through libraries or community organizations, for example. In cases where the "digital divide" cannot be crossed, alternative means of communication and participation should be provided (such as letter collection or recording of testimony).

Even in wealthy countries, there is a significant (albeit shrinking) "digital divide" along economic lines (Inter- 
national Telecommunication Union 2010). Some countries rely on traditional methods of contact, as in Ghana, where people rely on the use of traditional drum signals where telephones are unavailable (Foti et al. 2008). In this study, the Sri Lankan government demonstrated a sensitivity to communication access by relying on village-level governments and threewheeled taxis to monitor river flows and alert villagers to impending floods. In other countries, subsidization and official support for expansion of publicly available Internet and communications technologies helps to aid citizens in accessing information about local concerns.

\section{POLICY RESPONSE 4: REDUCE COSTS}

Design logistics and provide services and subsidies to lower the cost of accessing information, participation, and accessing justice forums.

Official fees for information are prohibitive for the poor. Participation, too, can incur high costs for community members and can prevent individuals from participating in meetings or events where they would otherwise make their voices heard. While reducing the costs of access to justice is more technically difficult, there are a number of steps that can be taken to accomplish this.

Travel costs, foregone work, official fees, time constraints, and unavailable childcare can all impact ability to participate and to access information. Travel involves not only commitments of time and money, but also entails risks to people and property. For that reason, there are a number of options to reduce the costs and risks:

- Holding consultations close to affected communities.

- Arranging transportation of representatives of affected communities to consultations.

- Contingency planning for travel barriers (especially seasonally inclement weather).

- Holding multiple consultations (to allow various members of households and neighborhoods to attend).

To address the high costs of participation from foregone labor and commitments of time, a basic step can be to schedule meetings after regular work hours and to hold more involved decision-making processes during seasons in which migrant laborers are at home and available. Additionally, it is important to consider the gender division of labor; women and men may be able to participate at different times of the day. To aid the participation of women, meetings might need to make childcare provisions or to maintain an open policy on children's attendance. Having multiple public participation events, or using models other than a traditional meeting such as a "drop-in" clinic, interviews, or doorto-door communication, may be more supportive of an individual's needs. Active solicitation of written comments or transcriptions of personal testimonies can also serve to lessen the time constraints individuals might feel.

Quality information engenders quality participation. As has been documented elsewhere, removal of all fees on accessing official documentation benefits the poor considerably. High official costs can be used as a means to block public access to information; for the poor, such costs might be entirely prohibitive. As an example, a government might charge exorbitant rates for paper and staff time to access a report on the health effects of a local dump. While the government may be complying in name with access to information requirements, poor individuals are unlikely to be able to access such documents. Below we outline ways to reduce costs for the poor, particularly for access to justice.

\section{Reducing the costs to initiate and carry out environmental litigation}

Enhancing legal aid and pro bono legal services (both governmental and non-governmental) for environmental matters is one step to reduce costs for individuals. Another possible measure includes establishment of alternative dispute resolution (ADR) mechanisms.

The poor face challenges in using justice mechanisms due to issues of cost, technical issues, and legal restrictions. To address these barriers, it is particularly critical that governments create and empower intermediary organizations to serve the interests of the poor. Options include supporting non-governmental organizations or private sector firms, direct government provision of legal services, and improvements in existing courts and tribunals.

Most individuals will access justice services with the help of lawyers or public interest advocacy professionals. Therefore, it is essential to create incentives to encourage and expand the capacity of intermediary organizations to represent the interests of individuals and communities living in poverty. This section out- 
lines a set of measures governments can undertake to encourage such advocacy, moving from least to most resource-intensive.

\section{Pro bono legal services}

Often, public interest organizations or attorneys provide legal services free of charge or at reduced rates.

Governments can take actions to increase incentives for such assistance through subsidies, for example, providing tax codes that allow attorneys to write off donated hours. This is a necessary, but ultimately insufficient means of providing legal services to the poor, as it is unlikely that small firms, even when income is augmented by grants, can devote significant energy and resources for protracted cases. While pro bono legal services will likely continue to play a significant part in most systems, additional measures are necessary to provide relief for members of poor communities seeking access to justice.

\section{Subsidizing public interest legal services}

Public interest legal services may be insufficient to cover the justice needs of the entire population, especially the poor. In response, governments have developed incentives to engage CSOs and the private sector (especially public interest law firms) to serve both the broad public interest and the needs of the poor. It is the role of courts or the legislature to define adequate eligibility criteria for "public interest organizations." If they are to address the needs of the poor, eligibility for public interest subsidies must include activities such organizations undertake on behalf of impoverished clients. The following reforms are ordered from least to most costly.

\section{Awarding or waiving litigation costs: At the most basic} level, governments can allow compensation claims by attorneys and clients to cover official costs incurred during lawsuits. In many jurisdictions, the loser pays the winner's costs (including lawyers' fees and travel expenses). Some jurisdictions waive such costs when a case meets a certain threshold of "public interest" or when a poor individual or community brings litigation. This serves to remove a major barrier to advocacy for the rights of the poor in environmental and other matters (Bonine 2008).

\section{Allowing for recovery of attorneys' fees during or after} trial: At their most generous, policies can encourage the engagement of public interest organizations by compensating attorneys for expenses incurred at a reasonable and predictable rate. Because of the often pro- tracted nature of disputes dealing with environmental matters, the court may choose to award such fees at reasonable intervals to public interest organizations. The specific compensation would need to be determined according to context in order to provide incentives for public interest representation while discouraging inappropriately protracted cases (Vogel 1980).

\section{Government supported legal and arbitration services}

Government agencies can better serve the justice needs of the poor by creating and supporting offices with incentives to protect poor communities and the resources they depend on. We outline two of the more common models here-ombudsmen/local defenders and alternative dispute resolution mechanisms.

\section{Ombudsmen, local defenders, and state attorneys}

Governments can provide services in a number of ways to represent the public's legal concerns in environmental matters. This can include advocacy on behalf of individuals, as undertaken by some ombudsmen's offices, or actual legal representation such as that provided by state attorneys offices. In Greece, the National Ombudsman for Housing and the Environment provided extensive representation of the public interest following the Peloponnesian fire of 2007 (Karageorgou 2008). In many countries of Latin America, local defenders or defensoras locales prosecute individuals and corporations who violate the law, including environmental law (Cox Urrejola et al. 2008). The cases evaluated by the Access Initiative Paraguay are all examples where the public defender's office took up the mantle of environmental defense. These models may be particularly promising in countries where there is little tradition of citizen enforcement of the law. To be effective, however, the mandate that designs the office must provide for processes guaranteeing equitable access to the poor. A considerable advantage provided by such offices is that they may have larger budgets to carry out the considerable evidence-gathering aspects necessary for environmental cases. Box 4 in the previous section offers a case study of a successful program.

\section{Alternative dispute resolution (ADR) mechanisms}

Judicial and administrative forums can be costly and slow. At times individuals or organizations may employ the services of alternative dispute resolution mechanisms instead. There are three common options, each of which can be useful for extending justice services to the poor. 
Conciliation is where the affected parties enter into discussions and a third party observes to make nonbinding recommendations; after a suitable resolution is found, parties may enter into appropriate contractual relationships to ensure follow-through. This model is useful for poor individuals or communities, because it saves considerable court and attorney costs. On the other hand, it assumes that the community will have sufficient wherewithal to negotiate a reasonable resolution and will subsequently be able to monitor and enforce whatever conditions for conciliation were agreed upon.

Mediation involves a third party charged with obtaining a negotiated resolution from disputants. The mediator cannot issues a binding resolution and parties can refuse to negotiate when they find the terms being offered unreasonable. Mediation can serve as an alternative when concerned parties do not wish to resort to adversarial means of dispute resolution, or where there is an existing gap in the law or no existing contract. Mediation can also be useful when disputants do not see official forums as neutral or appropriate. The case study, "Contamination of the Paraná River by Argentine Pulp Mills," is an example of where the law was silent on appropriate EIA procedure, because it concerned transboundary issues and required resolution through an appointed international body.

Arbitration is similar to traditional justice forums in that disputants agree to be bound by a third-party arbiter. Arbitration can lessen the caseloads of overworked courts, can offer specialized knowledge and services that rural courts might not otherwise be able to provide, and in some cases can be considerably more predictable and efficient. Importantly, ADR mechanisms-especially arbitration-are useless when there is no neutral official alternative. Citizens will rarely use forums that they see as predisposed toward the other party. For example, in the United States, despite the availability of such mechanisms for labor-ownership disputes in the early twentieth century, it took several decades before labor unions trusted such mechanisms sufficiently to engage them rather than using courts and strikes (Widner 2004).

Alternative dispute resolution is most useful when it serves as a complement to existing justice mechanisms, not as a substitute. Biased or unpredictable arbitration in the absence of a functioning official alternative can potentially be worse than providing no formal dispute resolution mechanism (Ribot 2002). The U.S. experience suggests that development of the judicial system and use of ADR can complement one another by creating needed relief for overburdened courts and courts with weak capacity (Widner 2004). According to researchers in this study, Paraguay has implemented dispute resolution forums for more that 25 years with some success. The Judicial Power has a Mediation Office, and there are two main ADR spaces-one in the Catholic University and one in the Paraguayan Chamber of Commerce (Abed 2008).

\section{Empowering courts to serve local populations}

Many countries have local courts or regularly traveling courts capable of resolving disputes. To the greatest extent possible, judges on such courts should build their capacity to understand natural resource and land law, including property law. This complicated subject is dealt with in depth in Greening Justice: Environmental Courts and Tribunals (Pring and Pring 2010) available at http:// www.accessinitiative.org/resources/greening-justice.

\section{POLICY RESPONSE 5: DEFEND THE ORGANIZATIONS AND INDIVIDUALS THAT PROMOTE ACCESS}

Support individuals and organizations that work to inform the poor through capacity building and awareness raising. This includes non-governmental organizations, local governments, and media outlets.

Steps can be taken to enable the organizations and individuals with an interest in informing the public to reach out to the poor. Examples of such steps include making sure that all environmental information for a relevant area is delivered to local elected officials, nongovernmental organizations, and media. A best practice is to require maintenance and publication of a list of organizations and media outlets to be contacted with environmental information and opportunities for participation.

Additionally, some countries need to strengthen protections for those who seek information and encourage participation. These reforms include whistleblower protections and institutionalizing freedom of association and assembly through clear, speedy, and apolitical procedures for registration of associations, including trade unions and cooperatives; limiting state interference in organizations' affairs; the right to free expression and cooperation (including across national boundaries); the right and ability to seek and secure resources; and protection from violence, intimidation, and threats (World Movement for Democracy 2008; Irish, Kushen, and 
Simon 2004). ${ }^{4}$ Training law enforcement officials on the importance of access to information and the need for protection of information solicitors can be essential, especially in countries emerging from authoritarian regimes or with high rates of intimidation of journalists or academics.

\section{POLICY RESPONSE 6: CLARIFY RESOURCE-RELATED RIGHTS AND REMOVE LEGAL BARRIERS OF STANDING AND EVIDENCE}

Establish clear legal rights to resource use by means such as property registration. Ensure that all individuals have lowcost, efficient means of obtaining legal identification. If such reforms cannot be achieved in the short run, rules of standing and evidence should be waived and loosened for poor individuals.

Based on our research, a key barrier to achieving access to justice for the poor includes issues of legal standing. Individuals may not have adequate evidence to show that they have a right to present their case in front of a justice forum. At times, this is because they cannot show that they had an interest in the resource or cannot document harm suffered through environmental degradation. In other instances, such as our cases from Cameroon, organizations attempting to bring a case in defense of diffuse or public interests were barred from doing so by standing restrictions limiting these cases to individuals.

Without proper documentation of rights to land and natural resources, individuals in the cases studied were unable to provide evidence of harm that would have been sufficient for just compensation. Removal of such barriers would not only complement other reforms, but would be essential to opening the courts, tribunals, and in some cases, participatory forums to all members of society. In our case studies, the Philippines Marcopper Mining Disaster most clearly highlighted the problems related to evidence and official documentation. Poor farmers harmed by the mining disaster were unable to provide documentation of productive land and livestock lost due to the disaster.

Indeed, steps are being taken in many countries to ensure that there is adequate land titling, and that individuals can obtain birth certificates, proof of residence, and official identification more easily. These steps are encouraging and will empower the poor to be better able to engage in decisions affecting the environment and to effectively enforce their right to a clean envi- ronment. Yet even though there is marked progress in these areas, many individuals will suffer environmental harms even though they have no official title to their land, few records of their assets, or no official identification. In these cases, justice mechanisms should be willing to enact rules waiving requirements for or reduce the importance of producing such documentation.

\section{POLICY RESPONSE 7: BUILD CAPACITY AND RAISE AWARENESS}

Promote the voice of poor individuals by improving their technical understanding of process and helping them overcome the lack of confidence and cultural barriers that can silence the poor in public processes.

In order to contribute to a decision-making process, individuals must feel sufficiently confident to participate and must be able to articulate their needs and demands. This requires not only technical training (as evidenced in cases where community members sit on management boards) but also requires education about the right to participate and the right to be heard. Officials, planners, and community organizations can be responsible for developing community capacity before a participatory event (Herbertson et al. 2009). One of the case studies from the Philippines, "Participatory Management of Biak-na-Bato National Park," showed how members of the community were able to successfully provide input into the management of a park once they were trained in the relevant processes. A number of other governments and organizations have developed citizens' manuals for public participation.

\section{POLICY RESPONSE 8: MAKE THE VOICE OF THE POOR INFLUENTIAL}

Meaningful participation requires both including stakeholders early enough in the process to influence decision-making and holding officials accountable to address the public's concerns. Facilitators must "go out of the way" to engage those members of the community who might not otherwise be consulted. The results of participation should be well documented and disseminated. Officials responsible for decisions and managing participation should be answerable for such processes.

In some contexts, forward-thinking governments, in partnership with other organizations, ensure that poor and minority communities are regularly contacted with regard to participation. Special consultations might be held to ensure that local voices are heard. In some places, this includes personal invitation of stakehold- 
ers by mail or through community-based organizations (such as places of worship) and public notices on signposts in affected areas. Local librarians, scientists, or health officials may be brought in ahead of time to make sure that community members have a better understanding of the impacts of a project or policy.

In the best cases, such participation creates a clear line of accountability. Participant voices are recorded and officials must justify, in writing, the reasons for their decisions in light of public input. Individuals should also be given additional information on who to contact should there be further questions or concerns.

\subsection{Four steps to institutionalize more inclusive access}

To make inclusive access a reality, governments, individuals, and organizations interested in making decisions more inclusive should take four steps to increase institutionalization of access rights. Voluntary measures outlined in the policy responses above will not, by themselves, guarantee decision-making procedures that include the poor.

In this section, we outline the steps for institutionalization. While we recognize that circumstances vary among countries, the development of access rights should have an increasingly permanent place within societies. In some countries, these rights may proceed sector by sector, while in others they may advance quickly through legislative reform. Over time, we hope that the right to a clean environment and supporting access rights will become not only universal, but that the poor will have the additional capabilities of rights to information, participation, and justice. ${ }^{5}$

To ensure that all citizens enjoy access, we recommend that governments take the following four steps:

1. Create access rights by developing the basic legal framework for access to information, public participation, and access to justice.

2. Ensure equal application of access rights by removing all forms of official discrimination against poor and marginalized communities and investing in the ability of all individuals to participate.

3. Ensure equal ability to use access by creating programs that reduce cost and improve means of communication.
4. Create additional rights that ensure the ability of the poor to use access rights.

\section{STEP 1: CREATE ACCESS RIGHTS}

While it may be argued that some countries provide access opportunities for their citizens without enacting legislation-often through voluntary actions by agencies or officials-establishing a legal right has repeatedly made a fundamental difference in the enforceability of access in many countries. As an example, Voice and Choice features a number of case studies in which a right to information made critical environmental information available to citizens (Foti et al. 2008).

The case studies suggest that application of the following rights supports access for the poor: a general right to a clean environment; access to information, public participation, and access to justice. The content of these rights has been covered extensively elsewhere (Petkova et al. 2002; Kiss and Shelton 2007; Kravchenko and Bonine 2008; Foti et al. 2008). Embodying them in national law is an important first step to ensuring that the poor enjoy access.

\section{STEP 2: ENSURE EQUAL APPLICATION OF ACCESS RIGHTS}

The countries studied in this survey all guarantee equal protection under the law. This is an important foundational principle because it enables advocates of access to the poor to use equality laws to ensure that procedures for access to information, public participation, and access to justice are carried out at the same minimum standard for all citizens. Actions within this category might include education on basic rights; litigation to ensure equal enforcement of the law; and improving online tools for access to information, public participation, and access to justice (where applicable). Equal application of access rights requires the least political and financial resources of the steps presented here and yet may be as far as some countries can go due to budgetary and political restraints. An especially important aspect of the equal application of rights will be a review and removal of the legal barriers that impede the poor, such as restrictions on women's right to inherit land. The method for review and removal of legal barriers is covered in Making the Law Work for Everyone, the report of the UNDP Commission on Legal Empowerment of the Poor (2008). 


\section{STEP 3: ENSURE EQUAL ABILITY TO USE ACCESS RIGHTS}

Even where individuals are treated equally, they do not always have the same ability to take advantage of opportunities for input into public decisions. To remedy this, governments can implement certain "best practices" to ensure that the poorest members of society are able to participate. Even where laws do not expressly support inclusive actions, agencies and other government bodies can mainstream the eight policy responses presented above. Examples of such efforts are found in many of the cases in this report, and have been undertaken in countries including South Africa, South Korea, and the United States in particular.

STEP 4: CREATE ADDITIONAL RIGHTS THAT ENSURE THE ABILITY OF THE POOR TO USE ACCESS RIGHTS

The most far-reaching step toward enforcing equal ability to use access is to create additional rights for poorer communities. As an example, a right to participate might be bolstered by additional legal obligations for decision-makers to consult all affected communities and publish results of all public participation during environmental impact assessments. Such a provision might give communities greater ability to demand consultation and even to halt a project that did not incorporate sufficient consultation. This significant level of rights has rarely been conferred on non-indigenous communities. The United States has acted as an interesting laboratory for the extension of access rights to poor communities, providing a relatively progressive model of inclusive and accountable decision-making. However, as of this writing, there are no specific additional rights for the poor or additional legal duties for governments.

\section{CRITICISMS AND CONSIDERATIONS OF MORE INCLUSIVE ACCESS}

As proponents of access and advocates for the poor consider extending access in decision-making, a number of criticisms are likely to emerge from those opposed to such policy reforms. Such concerns must be weighed against the ability of the poor to equally exercise the rights of access to information, public participation, and access to justice. It is the view of the authors that politically inclusive decision-making and steps to ensure equal enjoyment of a right take precedence over the concerns listed in Table 6 . In many cases poor individuals' sense of their ability to influence decisions can be as important to their livelihoods as pollution abatement. Table 6 presents criticisms against improving access for the poor along with issues to be considered when such objections are raised.

It is the position of this paper that a number of the criticisms outlined in Table 6 are relevant in particular circumstances. More importantly, however, many countries have elevated access principles to legal rights. In these cases, the duty to ensure that individuals can enjoy these rights may outweigh the above concerns. In cases in which scarce resources are allocated to access to information, public participation, and access to justice, preference should be given to including the poor, all other things being equal. 


\section{TABLE 6 CRITICISMS AND CONSIDERATIONS OF IMPROVING ACCESS FOR THE POOR}

\section{CRITICISMS}

\section{The data on disproportionate impacts and benefits is weak.}

In many countries, demographic, health, and environmental data are incomplete, making it difficult to find evidence that the poor are disproportionately impacted by decisions for the environment (Lao Rhodes 2005). As a result, an absence of evidence may be used as a justification to delay further action and expenditure.

\section{CONSIDERATIONS}

Benefits of participation include increased inclusion and greater legitimacy of decisions (Foti et al. 2008).

Within particular sectors, disproportionate impacts on the poor are more frequent (toxic waste siting, indoor air pollution, etc.). Targeting efforts toward impacts in these sectors can be particularly beneficial.

A similar harm suffered by a wealthy and a poor person does not have the same consequences. A principle of equity demands that we consider the disproportionate effects of environmental impacts and the risk of exposure compounded with other environmental factors.

\section{When data does show that there are disproportionate impacts and benefits, this could be the result of market forces rather than actual discrimination.}

There is evidence to suggest that disproportionate impacts are the result of personal choice rather than discriminatory policy (Arora and Cason 1996; Blackman, Blatz, and Evans 2003). For example, people may move closer to an already existing polluting facility because the cost of housing and land is cheaper.
While poor individuals may be rational actors making calculated decisions, they also may not have the same access to information about risks and exposures that they assume by following the market. Thus decision-makers evaluating cases of market-based disproportionate impacts should still consider what information disclosure and awareness raising is necessary to ensure that consumers are aware of the true costs of choices.

\section{The costs of additional participation are too high for government and business.}

Some say that inclusive participation is costly and that costs outweigh the benefits. Evidence of project delays due to participation is, however, hotly debated (Katz and Sara 1997; Reitbergen-McCracken 1996; Carroll, Schmidt, and Bebbington 1996; Aycrigg 1998; Lustig and Weiland 1998; Hentschel 1994).
Before assuming that additional or enhanced participation by poor communities will cost more, may delay projects and programs, or may require too much valuable staff time, decision-makers must weigh these short-term costs against the longer-term risks to project legitimacy and execution (Herz, Sohn, \& la Viña 2007).

Such costs must also be weighed against the ethical and legal considerations of involving poor communities.

\section{Providing additional access to justice for the poor will open the floodgates for too much litigation on discrimination.}

Some critics point out that lowering the costs and barriers to access to justice will result in a wave of negative unintended consequences. For one, critics argue that enabling litigants to sue for discrimination based on disparate impacts of decision-making, rather than evidence of active discrimination, is too low of a standard (Gerrard 2000). Such litigation could negatively impact broader development projects and undermine the ability of officials to make decisions in the interest of their respective communities (Pilon 2000).

\section{Additional participation will result in additional "NIMBYism."}

"Not-in-my-backyard," or "NIMBY," is a pejorative used to describe opposition to development of sites near a particular community. There is evidence suggesting that NIMBY activism can result in the placement of pollution in poor, ethnic minority, or less politically active communities (Bullard 1990; Arora and Cason 1996).
Litigation is one of a number of tools that can be used to ensure that communities have equal enforcement of rights. Access to justice may sometimes be achieved through dispute resolution, regulation, and voluntary mechanisms.

In certain circumstances, the will of the majority may override the rights of individuals. In such cases, just compensation for loss of life, property, and livelihood is essential.

While additional participation for the poor may not reduce the overall amount of NIMBYism, it strengthens the relative position of those communities that have often had an unequal voice in decision-making. 


\section{Conclusions}

The last 40 years have seen the blossoming of environmental rights and with them the ability of individuals to act to protect the resources they depend on. Access to information, public participation, and access to justice have been critical in ensuring that individuals have a voice in decision-making. In many cases, such rights have not been put in place or remain unfulfilled; in others, access is progressing by leaps; in others, it slowly advances through long struggles.

Even in those countries where access rights exist, all citizens have not enjoyed these rights equally. A Seat at the Table shows that key barriers that are particularly acute for the poor still exist, and these barriers prevent them from influencing major environmental decisions. In particular, individuals living in poverty face barriers of illiteracy, poor access to communication channels, high costs of access, risk, cultural expectations, and lack of official documentation. Yet the report also demonstrates some steps that governments have undertaken to design and implement policies and programs that address these barriers. The path to extending these rights will vary by country. Some do not yet have systems of governance conducive to basic access while others have more exhaustive procedures at most levels of government. Increasingly, however, governments, the private sector, and CSOs can learn from one another about innovations to include greater numbers of individuals in decision-making. We hope that this report is a helpful step in that direction.

Most importantly, we hope that CSOs and individuals already working to expand access will take up the banner of more inclusive and useful access. CSOs can aim to establish standards, build up citizen demand for access, and hold governments accountable for provid- ing access. CSOs engaged in legal battles can take on strategic cases that will help institutionalize the policy responses outlined in this paper.

Governments can also introduce and champion new standards of access and build on existing standards, working for implementation, expansion, and institutionalization of access rights. Some of this work will take place in legislatures through the passage of legislation. Other work will be led by forward-thinking agencies and individuals seeking fair implementation of existing laws and rules. In other cases, judicial systems will play a role in clarifying rights and responsibilities around access to information, public participation, and access to justice. Areas for innovation that relate to securing access for the poor are promising in the area of climate change with plans for funding and capacity building to reduce emissions due to deforestation and degradation (REDD).

Donors from both domestic and international organizations can work with CSOs to ensure that there are adequate funds to defend the rights of poor individuals and to advocate for reform of existing decision-making processes. Additionally, they can help to build the capacity of governments and to foster knowledge sharing about access implementation.

Over the next several years, the Access Initiative as well as WRI will continue its work to advance and broaden access, help to ensure that all individuals have the ability to exercise their access rights, and assist institutions in expanding their capabilities to foster more inclusive societies. 


\section{Sources}

Abed, P. 2008. Sentencia Picco Portillo. Asunción, Paraguay: Instituto de Derecho Ambiental. Available online at: http://www.accessinitiative.org/resource/sentencia-piccoportillo

Abed, P. and M. del Mar Zavale. 2008. Paraguay Poverty Report. Asunción, Paraguay: Instituto de Derecho Ambiental. Available online at: http://www.accessinitiative.org/poverty/pro-poor+access

Access Initiative. The Access Initiative. 2008. Available online at: http://www.accessinitiative.org/

The Access Initiative Research Tool. 2008. Available online at: http://www.accessinitiative.org/

African Centre for Technology Studies, Environmental Law Institute, Lawyers' Environmental Action Team, World Resources Institute. 2000. Environmental Procedural Rights in Africa: An Agenda for Reform. Paper presented for Africa's Ministers of the Environment at the Fifth Conference of the Parties to the Convention on Biological Diversity. Nairobi, May.

Agyeman, J. 2005. Sustainable Communities and the Challenge of Environmental Justice. New York: NYU Press.

Andrusevych, A., T. Alge, and C. Clemens. 2008. Case Law of the Aarhus Convention Compliance Committee. Lviv, Ukraine: Resource and Analysis Center "Society and Environment."

Arora, S. and T. Cason. 1996. Do community characteristics determine environmental outcomes? Evidence from the Toxics Release Inventory. Discussion Paper 97-12. Washington, DC: Resources For the Future.

Article 19. 2010. A Model Freedom of Information Law. Avail able online at http://www.article19.org/pdfs/standards/ modelfoilaw.pdf

Aycrigg, M. 1998. Participation and the World Bank: Success, constraints, and responses. Washington, DC: World Bank.

Banisar, D. 2008. Freedom of Information Around the World 2008: A Global Survey of Access to Government Records Laws. Washington, DC: Freedominfo.org.

Barendrecht, M. and P. van Nispen. 2008. Microjustice. TILEC Discussion Paper No. 2008-010. Available online at: http:// papers.ssrn.com/sol3/papers.cfm?abstract_id=1022936

Bass, R. 1998. Evaluating environmental justice under the National Environmental Policy Act. Environmental Impact Assessment Review 18(1): 83-92.

Blackman, A., M. Blatz, and D. Evans. 2003. Maquiladoras, Air Pollution, and Human Health, in Ciudad Juarez and El Paso. Washington, DC: Resources For the Future (22).

Bonfiglioli, A. 2001. Empowering the Poor: Local Governance for Poverty Reduction. New York: United Nations Capital Development Fund.

Bonine, J. 2008. Best practices-Access to justice: Agenda for public interest law reform. Washington, DC: The Access Initiative.
Bowen, W. 2002. An analytical review of environmental research: What do we really know? Environmental Management: 29(1).

Bryant, C. and C. Kappaz. 2005. Reducing Poverty, Building Peace. West Hartford, CT: Kumarian Press.

1993. Waste and racism: A stacked deck? Forum for Applied Justice and Public Policy 8(2): 29-35.

Bullard, R. 1990. Dumping in Dixie: Race, Class, and Environmental Quality. Boulder, CO: Westview Press.

Bullard, R., P. Mohai, R. Saha, and B. Wright. 2007. Toxic Wastes and Race at Twenty: 1987-2007. Cleveland, OH: United Church of Christ.

Cappelletti, M. 1993. Alternative dispute resolutions within the worldwide access to justice movement. Modern Law Review 56(3): 282-292.

Carroll, T., M. Schmidt, and T. Bebbington. 1996. Participation through intermediary NGOs. Washington, DC: World Bank.

Carruba, C. 2007. A model of the endogenous development of judicial institutions. Available online at: http://papers. ssrn.com/sol3/papers.cfm?abstract_id=999704

Carter Center. 2009. Atlanta Declaration on Access to Information. Atlanta: The Carter Center.

Commission on Legal Empowerment for the Poor (CLEP). 2008. Making the Law Work for Everyone: Volume 1- Report of the Commission on Legal Empowerment for the Poor. New York: United Nations Development Programme.

Cooke, B. and U. Kothari. 2002. Participation: The New Tyranny? New York: Palgrave.

Cox Urrejola, S., R. van Leeuwen, J. J. Faundes Merino, H. Vergara Leiva, and M. Castillo Pizaroo. 2008. Defensorías Locales: Análisis de Experiencias - Modelos de Réplica en América Latina. Santiago, Chile: Formación Jurídica para la Acción.

de Silva, S. 2007. The Access Initiative: Poverty Study. Colombo, Sri Lanka: Public Interest Legal Law Foundation. Available online at: http://www.accessinitiative.org/poverty/propoor+access

Excell, C. and K. Thompson. Forthcoming. Access to Justice in Decisions Affecting the Environment. Washington, DC: World Resources Institute.

Executive Order 12898. 1994. Federal Actions to Address Environmental Justice in Minority Populations and LowIncome Populations. 11 February.

Fernan., R., J. Florante Pamfilo, L. Gatlabayan, and M. Magalang. 2008. The Access Initiative - Poverty Assessment Report. Manila: Ateneo School of Government. Available online at: http://www.accessinitiative.org/poverty/pro-poor+access

Field, E. 2007. Entitled to Work: Urban property rights and labor supply in Peru. Quarterly Journal of Economics 122(4): $1561-1602$ 
Foreman, C.H. 1998. Inclusion. In The Promise and Peril of Environmental Justice. Washington, DC: Brookings Institution Press.

Foti, J., L. de Silva, H. McGray, L. Shaffer, J. Talbot, and J. Werksman. 2008. Voice and Choice: Opening the Door to Environmental Democracy. Washington, DC: World Resources Institute.

Frankfurter, F. 1949. Concurring opinion. Dennis v. United States, 339 U.S. 184. U.S. Supreme Court.

Gerrard, M. 2000. Environmental Justice: Legal Update. Albany, NY: National Academy of Public Administration and Government Law Center, Albany Law School. Available online at: http://www.napawash.org/EJ_Workshop_ Materials/Gerrard_EJLegUpdateDec05.pdf

Gloppen, S. 2004. The accountability function of the courts in Tanzania and Zimbabwe. In Democratization and the Judiciary, ed. S. Gloppen, R. Gargarella and E. Skaar, 112-136. Bergen, Norway: Chr. Michelsen Institute.

Goodland, R. 2008. WRI's Informative Memo for Access Law and Practice: Environmental and Social Assessment. Washington, DC: World Resources Institute.

Haklay, M. 2005. Does Aarhus make any sense? Questioning the provision of public environmental information. Presentation at RGS-IBG Annual International Conference, London.

Hardin, G. 1963. The tragedy of the commons. Science 162(3859): 1243-1248.

Hentschel, J. 1994. Does Participation Cost the World Bank More? Emerging Evidence. Washington, DC: World Bank.

Herbertson, K., M. A. Ballesteros, R. Goodland, and I. Muni1la. 2009. Breaking Ground: Engaging Communities in Extractive and Infrastructure Projects. Washington, DC: World Resources Institute.

Herz, S., J. Sohn, and A. la Viña. 2007. Development Without Conflict: The Business Case for Community Consent. Washington, DC: World Resources Institute.

Hirschman, A.O. 1970. Exit, Voice, and Loyalty: Responses to Decline in Firms, Organizations, and States. Cambridge, MA: Harvard University Press.

Huang, A. 2008. Phone interview. Natural Resources Defense Council. Conducted by author. November 20.

International Labour Organization Convention 169/1989. 1989. Indigenous and Tribal Peoples Convention. Geneva: International Labour Organization.

International Telecommunication Union. 2010. The Digital Divide at a Glance. Available online at: http://www.itu.int/ wsis/tunis/newsroom/stats/

Irish, L., R. Kushen, and K. Simon. 2004. Guidelines for Laws Affecting Civic Organizations. New York: Open Society Institute and the International Center for Not-for-Profit Law.

Karageorgou, V. 2008. Institutions promoting sustainability in Greece: Office of the Greek Ombudsman. Presentation given at the Conference on Environmental Governance and Democracy: Institutions, public participation and environmental sustainability: Bridging research and capacity development, New Haven, CT.

Katz, T. and J. Sara. 1997. Making rural water supply sustainable: Recommendations from a global study. Washington, DC: World Bank.
Kennedy, L. 1999. Cooperating for survival: Tannery pollution and joint action in the Palar Valley (India). World Development. 27(9): 1673-1691.

Kiss, A. and D. Shelton. 2007. Guide to International Environmental Law. Amsterdam: Martinus Nijhoff Publishers.

Kravchenko, S. and J. Bonine. 2008. Human Rights and the Environment. Durham, NC: Carolina Academic Press.

Kuldna, S. 2009. Personal Communication. April 19.

Lao Rhodes, E. 2005. Environmental Justice in America: A New Paradigm. Bloomington, IN: Indiana University Press.

Legault, S. 2009. Select Country Cases. Presentation at the Americas Regional Conference on the Right of Access to Information, Lima, Peru.

Lustig, S. and U. Weiland. 1998. The influence of Local Agenda 21 on local policy and the quality of decisionmaking: The pioneer city of The Hague. In Participation and the Quality of Environmental Decision-Making, ed. F. Coenen, D. Huitema, and J. L. O'Toole. Dordrecht, Netherlands: Kluwer Academic Publishers.

Massachusetts Executive Office of Energy and Environmental Affairs. 2002. Environmental Justice Policy of the Executive Office of Environmental Affairs.

2010. Environmental Justice Policy. Available online at: http://www.mass.gov/?pageID=eoeeaterminal $\& \mathrm{~L}=2 \& \mathrm{~L} 0=\mathrm{H}$ ome\&L1=Grants $+\% 26+$ Technical + Assistance $\&$ sid $=$ Eoeea\&b $=$ terminalcontent $\& \mathrm{f}=e e a \_s g s e \_e n v \_$equity\&csid=Eoeea

McDonald, D. A., ed. 2002. Environmental Justice in South Africa. Athens, OH: Ohio University Press.

Molinas, J. 1998. The impact of inequality, gender, external assistance and social capital on local-level cooperation. World Development 26 (3): 413-431.

Morrison, K., P.O. Ceruttie, P.R. Oyono, and M. Steil. 2009. Broken Promises: Forest Revenue Sharing in Cameroon. Washington, DC: World Resources Institute.

Neuman, L. 2009. Enforcement models: Content and Context. Access to Information Working Paper Series. Washington, DC: World Bank.

Olson, M. 1965. The Logic of Collective Action: Public Goods and the Theory of Groups. Cambridge, MA: Harvard University Press.

Ostrom, E. 1990. Governing the Commons: The Evolution of Institutions for Collective Action. Cambridge: Cambridge University Press.

Otero, C. 2007. Report on the Access Initiative and Poverty. Managua: Centro de Iniciativas Politicas Ambientales, Nicaragua. Available online at: http://www.accessinitiative. org/poverty/pro-poor+access

Ottoway, M. 2000. Social movements, professionalization of reform, and democracy in Africa. In Funding Virtue: Civil Society Aid and Democracy Promotion, ed. O. M. Ottoway and T. Carothers, 77-104. Washington, DC: Carnegie Endowment for International Peace.

Palerm, J. 2000. An empirical-theoretical analysis framework for public participation in environmental impact assessment. Journal of Environmental Planning and Management 43(5): 581-600. 
Petkova, E., C. Maurer, N. Henninger, and F. Irwin. 2002. Closing the Gap: Information, Participation, and Justice in Decision-Making for the Environment. Washington, DC: World Resources Institute.

Pilon, R. 2000. The Rule of Law in the Wake of Clinton. Washington, DC: Cato Institute.

Ponce, C., A. Briceño, and K. McHale. 2008. Freedom of association and assembly: Creating an adequate space for Civil Society and NGOs to operate. Washington, DC: The Access Initiative.

Price, M. and P. Krug. 2000. The enabling environment for free and independent media. Working Paper 027. New York: Cardozo Law School, Jacob Burns Institute for Advanced Legal Studies.

Pring, G. and C. Pring. 2010. Greening Justice: Creating Environmental Courts and Tribunals. Washington, DC: The Access Initiative.

Putnam, R. 1993. Making Democracy Work: Civic Traditions in Modern Italy. Princeton, NJ: Princeton University Press.

Ribot, J. 2002. Democratic Decentralization of Natural Resources: Institutionalizing Popular Participation. Washington, DC: World Resources Institute.

Rietbergen-McCracken, J. E. 1996. Participation in practice: The experience of the World Bank and other stakeholders. Washington, DC: World Bank.

Robeyns, I. 2005. The Capability Approach: A theoretical survey. Journal of Human Development 6(1): 93-114.

Rosenbaum, W. A. 2008. Environmental Politics and Policy. Washington, DC: CQ Press.

Roux, T. 2004. Legitimating transformation: Political resource allocation in the South African Constitutional Court. In Democratization and the Judiciary, ed. S. Gloppen, R. Gargarella and E. Skaar, 27-45. Bergen, Norway: Chr. Michelsen Institute.

Saldhana, L., A. Naik, A. Joshi, and S. Sastry. 2007. Green Tapism: A Review of the Environmental Impact Assessment Notification. Bangalore: Environmental Support Group.

Sama, N.J., P. Chili, P. Ndue, P. Galega, and E.B. Tawah. 2008. The Access Initiative: Cameroon National Report on the Poverty Project. Bamenda, Cameroon: Foundation for Environment and Development. Available online at: http://www. accessinitiative.org/poverty/pro-poor+access

Schwarte, C. and M. Adobewale. 2008. Environmental Justice and Race Equality in the European Union. London: Capacity Global.

Sen, A. 2001. Development as Freedom. Oxford: Oxford University Press.

Seo, W. 2002. Fighting Development Forces and Raising Public Awareness. Presentation delivered at Green Activism and Civil Society in South Korea, Woodrow Wilson International Center for Scholars, Washington, DC.

2008. The Access Initiative: Poverty Study 2. Colombo, Sri Lanka: Public Interest Legal Law Foundation. Available online at: http://www.accessinitiative.org/poverty/propoor+access

Stephenson, M. 2003a. Court of public opinion: Government accountability and judicial independence. Discussion paper No. 423. Cambridge, MA: Harvard Law School. 2003b. "When the Devil turns...": The political foundations of independent judicial review. The Journal of Legal Studies 32(1): 59-90.

United Nations Conference on Environment and Development (UNCED). 1992. Rio Declaration on Environment and Development.

United Nations Economic Commission for Europe (UNECE). 1998. Convention on Access to Information, Public Participation in Decision Making, and Access to Justice in Environmental Matters: Aarhus Convention, Adopted 25 June 1998 in Aarhus, Denmark, UN Doc. ECE/CEP/43, Entered into force 30 October 2001

United States Environmental Protection Agency. 1996. Guidance for Incorporating Environmental Justice Concerns in EPA's NEPA Compliance Analysis. Washington, DC: U.S. Environmental Protection Agency, Office of Federal Activities.

Vogel, D. 1980. The public-interest movement and the American reform tradition. Political Science Quarterly 95(4): 607-627.

Walker G. P., G. Mitchell, J. Fairburn and G. Smith. 2003. Environmental Quality and Social Deprivation. London: UK Environment Agency.

2005. Industrial pollution and social deprivation: evidence and complexity in evaluating and responding to environmental inequality. Local Environment 10(4): 361-377.

Webler, T., S. Tuler, and R. Krueger. 2002. What is a good public participation process? Five perspectives from the public Environmental Management 27 (3): 435-450.

White, T.A. and C.F. Runge. 1995. The emergence and evolution of collective action: Lessons from watershed management in Haiti. World Development. 23(10): 1683-1698.

Widner, J. 1999. Building judicial independence in Common Law Africa. In The Self Restraining State, ed. L. Diamond, M. Plattner, and A. Schedler, 177-194. Boulder, CO: Lynne Riener.

2001. Building the Rule of Law: Francis Nyalali and the Road to Judicial Independence in Africa. New York: W.W. Norton and Company.

2004. How some reflections on the United States' experience may inform African efforts to build court systems and the rule of law. In Democratization and the Judiciary, ed. S. Gloppen, R. Gargarella and E. Skaar, 27-45. Bergen, Norway: Chr. Michelsen Institute.

Wood, C. 1997. What has NEPA wrought abroad? In Environmental Policy and NEPA: Past, Present, and Future, ed. R. Clark. and L. W. Canter, Boca Raton, FL: CRC Press.

World Movement for Democracy. 2008. Defending civil society. Washington, DC: National Endowment for Democracy.

World Resources Institute. 2004. The Wealth of the Poor: Managing Ecosystems to Fight Poverty. Washington, DC: World Resources Institute.

Zheng, Y. and G. Walsham. 2008. Inequality of what? Social exclusion in the e-society as capability deprivation. Information Technology and People 21(3): 222-243. 


\section{Notes}

1. The Access Initiative is a global network of civil society organizations dedicated to ensuring that people have access to information, public participation, and access to justice in matters affecting the environment. The Access Initiative has partners in over 45 countries and works for reform of policy and practice through evidence-based advocacy. More can be found at http://www.accessinitiative.org.

2. Full case studies can be found at http://www.accessinitiative.org/poverty/node/509.

3. Country reports available at http://www.accessinitiative. org/poverty/pro-poor+access.
4. For a more complete list of the practical and legal requirements that enable CSOs to carry out advocacy, see Defending Civil Society published by the World Movement for Democracy (2008), Enabling Civil Society: Practical Aspects of the Freedom of Association from the Public Interest Law Initiative, and Guidelines for Laws Affecting Civic Organizations from the Open Society Institute (2004). Additionally, much of this report is based on the findings and recommendations of Foti et al. (2008), which offers a more general overview, including an assessment of basic laws and practices to enable CSO involvement in decisions affecting the environment.

5. The current status of these rights in the four countries that form the basis of this study is covered in an online Annex at http://www.accessinitiative.org/poverty/node/1086.

\section{About the Authors}

JOSEPH FOTI is an associate with The Access Initiative (TAI) at World Resources Institute. He was the lead author of Voice and Choice: Opening the Door to Environmental Democracy, TAI's second global report. He is currently leading work on WRI's toolkit for civil society engagement in climate change adaptation, is the regional officer for Latin America, and is spearheading work on access rights in the United States. He holds a B.A. from Antioch College and an M.A. in International Development Studies from The George Washington University.
LALANATH DE SILVA was a public interest litigator and advocate for over two decades. Pioneering the growth of public interest law in the area of the environment, he appeared in all of Sri Lanka's leading environmental cases on behalf of victims, communities and non-governmental organizations. He also worked for the Sri Lankan government for two years as the Legal Consultant to the Ministry of Environment and Forests. During that time he was responsible for drafting and enacting numerous regulatory provisions addressing noise, ozone depleting substances, and ambient air quality, among others. From 2002-2005 he served as a Legal officer in the Environmental Claims Unit of the United Nations Compensation Commission (UNCC) in Geneva. Together with a small group of international lawyers, he helped process the largest war reparations claims handled by the UNCC to monitor, assess, restore and compensate for environmental damage resulting from the 1991 Gulf War. Lalanath joined the World Resources Institute (WRI) in 2005 as the Director of The Access Initiative (TAI). 


\section{Athesess Initiative}

The Access Initiative (TAI) is the world's largest network of civil society organizations working to ensure that people have the right and ability to influence decisions about the natural resources that sustain their communities.

Working in their respective countries, TAI partners form national coalitions that assess the performance of their governments to provide the public with

- access to information about government decisions,

- public participation in decision-making, and

- access to justice when their rights to information, participation, and a clean environment are violated.

The right to obtain government information, right to participate in government decision-making, and the right to seek justice are a bundle of valuable rights which we call 'access rights.'

TAI Partners use assessments to advocate for legal, institutional, and practice reforms, raise public awareness, and engage their governments in a constructive dialogue to create change within their countries.

The World Resources Institute (WRI) functions as the Global Secretariat to TAI.

The World Resources Institute (WRI) is an environmental think tank that goes beyond research to create practical ways to protect the Earth and improve people's lives. Our mission is to move human society to live in ways that protect the Earth's environment for current and future generations.

Our programs meet global challenges by using knowledge to catalyze public and private action.

- To reverse damage to ecosystems. We protect the capacity of ecosystems to sustain life and prosperity.

- To expand participation in environmental decisions. We collaborate with partners worldwide to increase people's access to information and influence over decisions about natural resources.

- To avert dangerous climate change. We promote public and private action to ensure a safe climate and a sound world economy.

- To increase prosperity while improving the environment. We challenge the private sector to grow by improving environmental and community well-being.

In all its policy research, and work with institutions, WRI tries to build bridges between ideas and actions, meshing the insights of scientific research, economic and institutional analyses, and practical experience with the need for open and participatory decision making. 
